Illinois State University

ISU ReD: Research and eData

Theses and Dissertations

6-16-2020

\title{
The Underclass Culture Wars: Underclass Ideology And Neoliberalism In The Era Of Gangsta Rap Censorship, 1993-2000
}

Trumaine W. Mitchell

Illinois State University, trinity6700@yahoo.com

Follow this and additional works at: https://ir.library.illinoisstate.edu/etd

Part of the History Commons

\section{Recommended Citation}

Mitchell, Trumaine W., "The Underclass Culture Wars: Underclass Ideology And Neoliberalism In The Era Of Gangsta Rap Censorship, 1993-2000" (2020). Theses and Dissertations. 1300.

https://ir.library.illinoisstate.edu/etd/1300

This Thesis is brought to you for free and open access by ISU ReD: Research and eData. It has been accepted for inclusion in Theses and Dissertations by an authorized administrator of ISU ReD: Research and eData. For more information, please contact ISUReD@ilstu.edu. 


\section{THE UNDERCLASS CULTURE WARS: UNDERCLASS IDEOLOGY AND NEOLIBERALISM IN THE ERA OF GANGSTA RAP CENSORSHIP, 1993-2000}

\section{TRUMAINE W. MITCHELL}

\section{Pages}

My thesis explores the impact of underclass ideology and the budding neoliberal consensus on black censorship efforts against gangsta rap music in the 1990s and early 2000s. While there are a few scholarly works that focus on blacks' involvement in the gangsta rap censorship movement, they fail to provide any serious inquiry into their ideological motivations for pursuing censorship. In an effort to fill this gap, my thesis looks at underclass ideology and neoliberalism in relation to two groups that were active in the gangsta rap censorship movement: black liberals and the Nation of Islam (NOI).

I argue that censors took issue with the genre because they saw it as promoting social pathology among African Americans. During the 1990s, crime, violence, broken families, and a host of other social issues had become synonymous with African-American communities in American politics and culture, and black censors felt that limiting black people's access to gangsta rap could ameliorate these issues. Censors felt an urgent need to suppress gangsta rap, as the Clinton administration used the type of black stereotypes promoted in the genre to justify taking a hardline approach to black criminality and cutting off welfare for black families. Like others swept into the orbit of underclass ideology and neoliberalism, black censors shared two widely-held assumptions about African Americans that informed their critiques of the genre: 
one, that they exhibited pathological behavior; and two, that black social pathologies could be ameliorated by pursuing measures that would curtail antisocial behavior.

KEYWORDS: Underclass ideology, neoliberalism, gangsta rap, politics 
THE UNDERCLASS CULTURE WARS: UNDERCLASS IDEOLOGY AND

NEOLIBERALISM IN THE ERA OF GANGSTA RAP

CENSORSHIP, 1993-2000

TRUMAINE W. MITCHELL

A Thesis Submitted in Partial Fulfillment of the Requirements for the Degree of

MASTER OF SCIENCE

Department of History

ILLINOIS STATE UNIVERSITY

2020 
Copyright 2020 Trumaine W. Mitchell 
THE UNDERCLASS CULTURE WARS: UNDERCLASS IDEOLOGY AND

NEOLIBERALISM IN THE ERA OF GANGSTA RAP

CENSORSHIP, 1993-2000

TRUMAINE W. MITCHELL

COMMITTEE MEMBERS:

Toure F. Reed, Chair

Kyle Ciani

Andrew Hartman 


\section{ACKNOWLEDGMENTS}

Since completing a lengthy research project such as this one is never a lone effort, I would like to thank a few individuals who helped me see it through to the end. First, I would like to thank my chair Toure F. Reed for helping me structure my thesis. Beyond his help in this regard, he has helped to shape my understanding of black history through our many long conversations, for which I am forever in his debt. I would also like to thank my second reader Kyle Ciani. Her comments allowed me to refine my gender analysis and improve my grammar, which I believe has helped me produce a more solid thesis. Andrew Hartman also has my warmest regards, whose book on the culture wars led me to ISU to study under him and convinced me to undertake a study on black gangsta rap censorship. I would also like to thank Katrin Paehler. Though she was not directly involved in the project, her comments on a seminar paper, along with Reed's, helped me realize the limitations of how I originally approached my topic, and led me to construct an argument that I believe has made for a better thesis.

I would also like to thank my family for their emotional support and for giving me the space and time that I needed to work, and for having the patience to put up with me on days when I got frustrated with the project. A special thank you to my mother, who encouraged me to take up the study of history. Lastly and most importantly, I want to give thanks to God, whom without none of this would have been possible.

T. W. M. 


\section{CONTENTS}

\section{Page}

ACKNOWLEDGMENTS

$\begin{array}{ll}\text { CONTENTS } & \text { ii }\end{array}$

$\begin{array}{ll}\text { INTRODUCTION } & 1\end{array}$

CHAPTER I: UNDERCLASS IDEOLOGY AND FEDERAL POLICY, 1961-1996 11

$\begin{array}{ll}\text { Conclusion } & 33\end{array}$

CHAPTER II: BLACK LIBERAL RESPONSES TO GANGSTA RAP, 1993-2000 36

$\begin{array}{ll}\text { Crime/Violence } & 38\end{array}$

$\begin{array}{ll}\text { Sexual Promiscuity } & 49\end{array}$

Family Disorganization $\quad 51$

$\begin{array}{ll}\text { Conclusion } & 57\end{array}$

CHAPTER III: THE NATION OF ISLAM'S RESPONSES TO GANGSTA RAP, 1995-2000 59 The NOI and Black Pathology: A Literature Review $\quad 61$

Million Man March and Gangsta Rap $\quad 63$

$\begin{array}{ll}\text { Crime/Violence } & 65\end{array}$

$\begin{array}{ll}\text { Sexual Promiscuity } & 70\end{array}$

$\begin{array}{ll}\text { Family } & 71\end{array}$

$\begin{array}{ll}\text { Analysis } & 73\end{array}$

$\begin{array}{ll}\text { Rappers } & 74\end{array}$

$\begin{array}{ll}\text { Conclusion } & 76\end{array}$

$\begin{array}{ll}\text { CONCLUSION } & 78\end{array}$ 
BIBLIOGRAPHY 


\section{INTRODUCTION}

In 1977, Time magazine published an article that discussed the burgeoning American underclass. Bypassing any mention of the role that deindustrialization, automation, and public policy played in its development, the article described the underclass strictly in terms of race and social pathology: it was mainly comprised of poor urban blacks who tended to be welfare recipients, juvenile delinquents, drug users, and adult-aged criminals. Despite civil rights gains, an expansion of affirmative action and antipoverty programs, steady job growth, and a growing black middle class, the underclass proved unable to take advantage of these opportunities, the article continued, because it suffered from "psychological and material destitution" that was most likely the result of institutional racism. The article then proposed several solutions to the issues facing the underclass, like supporting harsh punishments for criminal offenders and endorsing President Jimmy Carter's “"profamily, pro-work”" welfare reform bill, which would be used to combat dependency and family dissolution among its members. ${ }^{1}$ With its analysis, the article anticipated many of the characterizations of and policies for the underclass that former president Ronald Raegan would make popular during his presidency.

At first glance, it seems that this detailed description of the underclass has little, if anything to do with music censorship. However, the underclass served as a major impetus behind black involvement in the gangsta rap censorship movement in the 1990s and early 2000 s. $^{2}$ Initially targeted by white conservatives, the genre began to be heavily criticized by black liberals in 1993, and later by the Nation of Islam. An important cornerstone of their criticisms

\footnotetext{
1“The American Underclass," Time (EBSCOhost), August 29, 1977, 18, accessed May 9, 2020, https://eds-bebscohost-com.libproxy.lib.ilstu.edu/eds/de tail?vid=9\&sid=9660cfd1-1dcd-4b9c-b94d-9e813cb9bdfd\%40pdcvsessmgr05\&bdata=JnNpdGU9ZWRzLWxpdm Umc2NvcGU9c210ZQ\%3d\%3d\#AN=53520812\&db=a9h. ${ }^{2}$ While the spelling of the word "gangster" is incorrect, this is how rap artists, journalists, commentators, and others utilized the term when discussing the genre. In the interest of accuracy, I will be using this spelling for the duration of the study.
} 
was underclass ideology-the belief that issues like crime, poverty, and welfare dependency were connected to group behavior and culture rather than political economy. Many of their critiques seem reasonable when looking at the genre and its subject matter.

Gangsta rap is a sub-genre of rap that originated in Los Angeles in the mid-1980s. While rappers like Ice-T and Schoolly D are credited with founding the genre, it became popular with the release of Niggaz Wit Attitudes (N.W.A.)'s 1988 debut Straight Outta Compton, an album that served as a critique of the Los Angeles Police Department (LAPD)'s maltreatment of African Americans. The genre was controversial, as it often incorporated lyrics that referenced gang culture, drug usage, and misogynistic acts. ${ }^{3}$

By the late 1980s, gangsta rap would find itself in the crosshairs of a censorship movement. While organized censorship efforts against music date back to the 1950s, music censorship reached its height by the mid-1980s. ${ }^{4}$ Groups like the Parents Music Resource Center (PMRC), organized by "Washington Wives" Tipper Gore, Susan Baker, Pam Howar, and Sally Nevius, initially lead the fray against rock artists, pressuring record stores not to sell their music and organizing a Senate hearing on rock music, which culminated with record companies agreeing to place Parental Advisory labels on albums that were considered explicit. Conservatives also targeted rap music. While they voiced their criticism of Ice T's and N.W.A.'s sexually-explicit albums, the brunt of their censorship efforts was directed toward porno rap group 2 Live Crew. Many called for an outright ban on their sexually-charged album As Nasty as

\footnotetext{
${ }^{3}$ Bryan J. McCann, Mark of Criminality: Rhetoric, Race, and Gangsta Rap in the War-On-Crime Era (Tuscaloosa: University of Alabama Press, 2017), 34-53, 68.

${ }^{4}$ Claude Chastagner, "The Parents' Music Resource Center: From Information to Censorship," Popular Music 18, no.2 (1999): 183.
} 
They Wanna Be. Conservative lawyer Jack Thompson even prosecuted the group on obscenity charges for having performed the album's lyrics at a concert venue. ${ }^{5}$

Scholars have looked at rap censorship in the context of the culture wars. While the term "culture wars" was originally used to describe the conflict between German liberals and Catholic conservatives over the role of the Church in German society in the 1870s (Kulturkampfe), it has taken on new meaning in its American context. ${ }^{6}$

James Davidson Hunter pioneered the scholarly study of the American culture wars in his groundbreaking text Culture Wars: The Struggle to Define America. According to his argument, groups are in a constant struggle to impose their morals, beliefs, and principles on American society. While this conflict initially took place between religious groups (i.e. Catholics, Protestants, Mormons, Jews,) in the $19^{\text {th }}$ and early $20^{\text {th }}$ centuries, Hunter contends that the new culture wars in the last few decades of the $20^{\text {th }}$ century were taking place between two vaguely defined "polarizing impulses"-orthodoxy and progressivism. ${ }^{7}$ He defines orthodoxy, for example, as the "commitment on the part of adherents to an external, definable, and transcendent authority" while progressivists "[tend] to resymbolize historic faiths according to the prevailing assumptions of contemporary life." ${ }^{8} \mathrm{He}$ asserts that cultural conservatives and liberals, respectively, embrace these impulses while promoting their brand of American life in several "fields of conflict," including the family, education, media and the arts, law, and politics. ${ }^{9}$

Many scholars have used Hunter's concept of "polarizing impulses" to make sense of rap censorship. Andrew Hartman, for instance, argues that the 2 Live Crew episode in the censorship

\footnotetext{
${ }^{5}$ Andrew Hartman, A War for the Soul of America: A History of the Culture Wars (Chicago: Chicago UP, 2015), 177-180. ${ }^{6}$ Hartman, A War for the Soul of America, 297.

${ }^{7}$ James Davidson Hunter, Culture Wars: The Struggle to Define America (New York: Basic Books, 1991), 35-42.

${ }^{8}$ Hunter, Culture Wars, 44-45.

${ }^{9}$ Hunter, Culture Wars, 46, 50-51.
} 
movement was an outgrowth of the conflict between New Left and neoconservative sensibilities that had fueled the American culture wars since the 1960s. ${ }^{10}$

Scholars have also attempted to fit black censors within this narrow culture wars framework. Describing her as a "[c]ultural war activist," historian Jeffrey O. G. Ogbar explains how C. Delores Tucker, a black politician, and William Bennett, who had served in the Reagan and George H. W. Bush administrations, pressured Time Warner to sell its stake in Interscope Records in 1995, a company that was known for producing gangsta rap. Ogbar opines that they did so because they were concerned about how the genre contributed to the moral degradation of American youth. ${ }^{11}$

Aside from the culture wars, scholars have also used a generational/civil rights framework as a way of explaining black censors' responses to gangsta rap. Scholars who embrace this framework argue that black censorship grew out of a generational conflict between the civil rights and hip-hop generations. ${ }^{12}$ For them, censorship was the result of the former, which tended to be made up of older, middle-class blacks, trying to impose their morals and values on rappers (the hip-hop generation), whose lyrics left them at odds with the previous generation. Middle-class blacks, they further argue, often cited the Civil Rights Movement (1954-1968) in their arguments against gangsta rap, which they felt embodied the morals and values of their generation. Highlighting how black censors like Tucker, Rev. Jesse Jackson, and Senator Carol Moseley-Braun often drew on civil rights rhetoric as justification for their

\footnotetext{
${ }^{10}$ Hartman, A War for the Soul of America, 180-183.

${ }^{11}$ Jeffrey O. G. Ogbar, "Slouching Toward Bork: The Culture Wars and Self-Criticism in Hip-Hop Music," Journal of Black Studies 30 (1999): 165-166.

${ }^{12}$ The "hip hop generation" is a term popularized by journalist Bakari Kitwana in his book of the same name. Born between 1965 and 1984, Kitwana contends that this generation has been shaped by several historical developments, including globalization, deindustrialization, and mass incarceration. He further argues that this generation is constantly at odds with the civil rights/Black Power generation, since the latter has shown an "unwillingness...to adjust to the social transformations that have shaped the hip-hop generation." (23). See Bakari Kitwana, The HipHop Generation: Young Blacks and the Crisis in African-American Culture (New York: Basic Books, 2003), 11-23.
} 
censorship efforts, for example, Bryan J. McCann sums up black censorship as a "generational battle over the mobilization of black affect toward middle-class sensibilities on the one hand and criminalized leisure and style on the other." ${ }^{13}$ While rather critical of gangsta rap censorship, arguing that it obscured how deindustrialization and neoliberalism contributed to "social disintegration" in black urban areas, George Lipsitz also looks at how censors drew on the lessons of the Movement to make their case against gangsta rap. ${ }^{14}$

While both the culture wars and generational conflict frameworks provide insight into the type of rationales that motivated individuals and groups to censor gangsta rap, scholars have applied them in such a way that promote a narrow understanding of the black backlash against the genre. Their tendency to either place censors within a rigid liberal-conservative dichotomy or to trace their criticisms to their collective memory of the Civil Rights Movement causes them to disregard other political and ideological concerns that informed their criticisms of the genre. While the former suggests that censors, regardless of race, pursued censorship for similar reasons, the latter assumes that black censorship efforts can be understood without considering contemporaneous political and ideological trends in American society.

Rather than simply being a facet of the broader culture wars or a site of generational conflict, then, black gangsta rap censorship was reflective of a conservative turn in American politics that was informed by underclass ideology. The underclass is a subject that has been of interest to social scientists, journalists, policymakers, and politicians since the late 20th century. The term was first used in social science research by Gunnar Myrdal, who used it to describe a segment of the American population that was poor and socially alienated from the rest of society.

\footnotetext{
${ }^{13}$ McCann, Mark of Criminality, 84.

${ }^{14}$ George Lipsitz, "The Hip Hop Hearings: Censorship, Social Memory, and Intergenerational Tensions Among African Americans," in Generations of Youth: Youth Culture and History in Twentieth-Century America, eds. Joe Austin and Michael Nevin Willard (New York: New York University Press, 1998), 395, 402, 404.
} 
While social scientists initially looked at the underclass largely in the context of political economy, the concept would later be used to define groups in terms of race, culture, and behavior. $^{15}$

Daniel Patrick Moynihan, the Assistant Secretary of Labor in both the Kennedy and Johnson administrations, was one of the earliest social scientists to link the underclass to race, culture, and behavior. In his influential 1965 study The Negro Family: A Case for National Action, for instance, he argued that while African Americans had attained their full civil rights, they would continue to be burdened with issues like poverty and unemployment because of the debilitating effects that institutional racism had on the black family structure, which he argued was evident with the emasculation of black males and female-led families. ${ }^{16}$ Arguing that such conditions were evidence of black pathology, Moynihan stressed to President Johnson that any efforts to redress black economic inequality had to target blacks' supposed dysfunctional behavior and culture. Drawing from Moynihan's recommendations, Johnson initiated the Great Society, which funded programs that were largely geared toward combating poverty by way of correcting poor minorities' supposed character flaws. Moynihan's analysis was important because it set the terms for how future social scientists and government officials would analyze, and set policy recommendations for, the black underclass. ${ }^{17}$

\footnotetext{
${ }^{15}$ Alice O' Conner, Poverty Knowledge: Social Science, Social Policy, and the Poor in Twentieth-Century U.S. History (Princeton: Princeton UP, 2001), 266-267.

${ }^{16}$ From Moynihan going forward, social scientists, politicians, policymakers, and journalists tended to attribute negative stereotypes associated with the black underclass, like single-parent, female-headed families, to black women. In the 1980s, however, writers began to critique such assessments about black women. See, for instance, Paula Giddings, When and Where I Enter: The Impact of Black Women on Race and Sex in America (New York: William Morrow and Company, Inc., 1984), 325-335.

${ }^{17}$ Toure F. Reed, "Why Moynihan Was Not So Misunderstood at the Time: The Mythological Prescience of the Moynihan Report and the Problem of Institutional Structuralism," nonsite.org, September 4, 2015, accessed May 9, 2020, http://nonsite.org/article/why-moynihan-was-not-so-misunderstood-at-the-time.
} 
By the 1980s, the black underclass had become a growing subject of interest among social scientists, journalists, politicians, and policymakers. During this period, poverty had increased in black urban areas despite the Great Society's antipoverty programs. This was accompanied by a rise in crime, out-of-wedlock births, unemployment, and several other conditions. Rather than identifying deindustrialization as a root cause of these conditions, conservative scholars, such as Charles Murray, and politicians, such as President Ronald Reagan, argued that the Great Society's welfare programs had exacerbated, rather than ameliorated, poverty by promoting dependency and immorality among the poor. ${ }^{18}$ By the early 1990 s, liberal Democrats had also come to embrace underclass ideology, resulting in a bipartisan commitment to discouraging underclass pathologies via tough-on-crime legislation and welfare reform. With its emphasis on disciplining poor people who were disproportionally African American and Latino, underclass ideology was an important facet of the burgeoning neoliberal consensus. This new approach found its greatest expression in two acts that were endorsed by former president Bill Clinton: the Violent Crime Control and Law Enforcement Act of 1994 and the Personal Responsibility and Work Opportunity Act of 1996. While the former sought to curtail criminality by imposing a mandatory life sentence on repeat offenders, the latter sought to discourage dependency by limiting the number of years a person could receive welfare benefits. ${ }^{19}$ Many liberals and conservatives argued that the latter would also reduce illegitimacy and promote the formation of nuclear families, since it was believed that it would disincentivize women from having babies out-of-wedlock. ${ }^{20}$

\footnotetext{
${ }^{18}$ Elizabeth Hinton, From the War on Poverty to the War on Crime: The Making of Mass Incarceration in America (Cambridge: Harvard UP, 2016), 308.

${ }^{19}$ Daryl A. Carter, Brother Bill: President Clinton and the Politics of Race and Class (Fayetteville: University of Arkansas Press, 2016), 49-50, 114-115, 170.

${ }^{20}$ Carter, Brother Bill, 182. In addition to its welfare policies, the Clinton administration also passed the 1993 Family and Medical Leave Act, which allows employees to take leave from their jobs for up to 12 weeks in a year for
} 
Given this, there are many advantages to looking at black gangsta rap censorship in the context of underclass ideology and the rightward shift in American politics. First, it shows that gangsta rap censorship was much more than a culture wars or generational issue; black censors set out to suppress what they believed to be a major contributor to black social pathologies. Second, this approach helps to deepen our understanding of the broad appeal of behavioral rather than political-economic understandings of racial and economic inequality. It also helps to show that African-American political agency cannot be neatly categorized as liberal or conservative.

Chapter 1 looks at the origins and development of underclass ideology and how it manifested in federal policy from 1961 until 1996. First, the chapter provides a brief overview of American politics, showing how a rightward shift in post-WWII American politics informed how politicians and policymakers sought to redress black social issues. After examining the culture of poverty framework's influence over the anti-delinquency and antipoverty measures of the Kennedy and Johnson administrations, respectively, the chapter then considers how underclass ideology affected Nixon's "law and order" policies. Against the backdrop of neoliberalism, the chapter then details how underclass ideology enjoyed bipartisan support from conservative Republicans and liberal Democrats. It then gives an in-depth overview of the anti-crime and welfare reform bills and how blacks responded to them. Blacks' general support of crime prevention and welfare reform highlighted their commitment to underclass ideology and neoliberalism, which served as the intellectual foundation for them to rest their claims about the benefits of censorship.

Chapter 2 then looks at black liberals' criticisms of gangsta rap. It considers four issues that they felt the genre exacerbated among its African-American audience: crime, violence,

family and medical related reasons. See Deborah L. Drexler, "Basic Requirements of the Family and Medical Leave Act," The Compleat Lawyer 10, no.4 (Fall 1993): 6-8. 
sexual promiscuity, and family disorganization. First, the chapter analyses several black liberals' thoughts on the genre and their proposed efforts to subdue its supposed influence on black criminality and violence. With sexual promiscuity, the chapter explores the ways in which critics sought to counter the negative influence they believed the genre had on black female sexual behavior. Finally, with family disorganization, the chapter looks at how censors linked gangsta rap to facets of dysfunctional black family life, such as irresponsible fathers and unruly children.

Chapter 3 explores the NOI's censorship efforts in relation to these same issues.

Following an examination of NOI scholarship and the Million Man March, the chapter considers how Conrad Muhammad and Louis Farrakhan used the March's themes of atonement, reconciliation, and responsibility to combat violence and criminality among rappers and their black listening audience. It also looks at events inspired by the March, such as the Million Woman March and the Million Family March, and delves into how they were used to challenge gangsta rap's supposed advocacy of black female sexual promiscuity and family disorganization, respectively. Both the NOI's and black liberals' censorship efforts showed their preference for behavioral solutions to black social problems, so this chapter, more so than the previous ones, examines how black rap censorship can help us understand the rightward shift in black politics in the 1990s. Believing that rap could also be used to cure blacks of these issues, the chapter concludes by looking at rappers who embraced the NOI's belief, and how their music was in accordance with the organization's censorship aims.

The conclusion analyzes rap criticism after 2000, after major censorship initiatives had declined. It looks at the criticisms of prominent black liberals like Bill Cosby and Barack Obama, and those of Louis Farrakhan. It then looks at how issues tied to the black underclass, like crime and family disorganization, persisted during this period despite continued criticisms of 
the genre and calls for censorship. Finally, it considers how behavioral approaches have always been insufficient in dealing with issues that have plagued African Americans in the post-WWII era, and how a reformation of American politics is needed to properly address these issues. 
CHAPTER I: UNDERCLASS IDEOLOGY AND FEDERAL POLICY, 1961-1996

On August 25, 1994, Congress passed the Violent Crime Control and Law Enforcement Act. An anti-crime law, it contained some of the most punitive provisions that would come to have a disproportionate effect on poor people of color in subsequent years: mandatory life sentences for repeat offenders, drastic cuts to educational programs for inmates, and increased police presence in black urban areas. ${ }^{21}$

On August 22, 1996, Congress also passed the Personal Responsibility and Work Opportunity Act. A welfare reform law, it contained provisions that would also have a negative impact on poor minorities. One such provision repealed Aid to Families with Dependent Children (AFDC) and replaced it with Temporary Aid to Needy Families (TANF), which forced millions of African Americans into low-paying jobs that offered no escape from poverty nor welfare dependency. ${ }^{22}$

For then-president Bill Clinton, these laws were the realization of a long-fought effort to curtail crime and reform the welfare system. Running his 1992 presidential campaign on promises to get " "tough on crime" ${ }^{23}$ and "end welfare as we know it," ${ }^{24}$ Clinton, along with his African-American constituency, New Democrats, and Republicans, supported punitive measures to lessen crime and dependency.

These laws were the culmination of decades-long efforts made by social scientists, politicians, and policymakers to redress black social issues by "fixing" black behavior. Faced with mounting poverty, delinquency, and crime in black urban areas, politicians like John F.

\footnotetext{
${ }^{21}$ Carter, Brother Bill, 114-115.

${ }^{22}$ Carter, Brother Bill, 193, 197-198.

${ }^{23}$ Gwen Ifill, "THE 1992 CAMPAIGN: The Democrats; Clinton, in Houston Speech, Assails Bush on Crime Issue," New York Times (Nexis Uni), July 24, 1992, accessed May 19, 2020, https://advance-lexis.com.libproxy.lib.ilstu.edu /api/document?collection=news\&id= urn:contentItem:3SC4-7YM0-000P-24WB-00000-00\&context=1516831.

${ }^{24}$ Carter, Brother Bill, 181.
} 
Kennedy and Lyndon B. Johnson sought to address these issues by developing federal policies that focused on character building and fostering strong families. By the 1980s, conservative social scientists and politicians had come to embrace the view that punitive, rather than soft prevention policies, could suppress crime, poverty, and dependency, which came to be increasingly associated with inner-city blacks. Liberal Democrats also began to accept this article of faith by the early 1990s, resulting in bipartisan support for the laws mentioned above.

This chapter traces the origins and development of underclass ideology from the 1960s to the 1990s. After a brief synopsis on American politics from the 1930s to the 1960s, it examines how social scientists like Moynihan informed federal policies and programs geared toward African Americans in the 1960s and 70s. Against the backdrop of deindustrialization, globalization, and neoliberalism, it then considers how underclass ideology encouraged Raegan to pursue punitive policies against poor, inner-city people of color in the 1980s. Finally, it discusses the bipartisan support of underclass ideology with the New Democrats, and how this affected Clinton's policies toward minorities.

This chapter also considers how African Americans responded to the crime prevention and welfare reform bills. Blacks generally supported the bills, albeit for different reasons: some supported their more punitive measures while others felt that their soft preventative provisions were more useful. Their attitudes reveal that they were as invested in the idea that behavior was a major cause of black social issues as liberal Democrats and conservative Republicans were. This is important because it helps to understand the rationale behind black censors' censorship efforts.

The New Deal, which were a set of domestic policies and programs created by the Roosevelt administration (1933-1945) aimed at alleviating the economic devastation caused by the Great Depression, ushered in what historian Toure F. Reed has called the "public interest 
model of government." ${ }^{25}$ This form of governance, which dominated American politics roughly from the 1930s to the 1960s, promoted the idea that it was the federal government's responsibility to promote the public good by ensuring that Americans were ensured their civil rights and had equal access to adequate housing, education, jobs, healthcare, and a social safety net. ${ }^{26}$ Given the latter, liberals, leftists, and progressives prior to 1945 often advanced policies that linked racial and working-class concerns. Organizations like the National Urban League (NUL), the National Association for the Advancement of Colored People (NAACP), and the National Negro Congress (NNC), for instance, often saw interracial working-class solidarity as an important prerequisite to racial equality, and therefore supported black labor disputes and black involvement in unions toward this end. ${ }^{27}$

This consideration of the interplay between racial and working-class issues became less of a staple in American politics after World War II. During the early Cold War, the Republican and Southern Dixiecrat-led Congress began to undo the labor gains of the New Deal by passing the 1947 Taft-Hartley Act and utilizing the House Un-American Activities Committee (HUAC), both of which curtailed the strength of the union movement. ${ }^{28}$ Due to this attack on workingclass interests, liberal policymakers began to address racial issues in a way that was divorced from political economy. Reed, for instance, notes that while the civil rights legislation of the 1960s was in line with the public good model of governance inaugurated by the New Deal, it was "incapable of redressing the structural economic sources of racial disparities." ${ }^{29}$ Such a lack of commitment to political-economic solutions to racial inequality would shape the way politicians,

\footnotetext{
${ }^{25}$ Toure F. Reed, Toward Freedom: The Case Against Race Reductionism (New York: Verso Books, 2020), 15.

${ }^{26}$ Reed, Toward Freedom, 2-5.

${ }^{27}$ Reed, Toward Freedom, 28-40.

${ }^{28}$ Reed, Toward Freedom, 54-55.

${ }^{29}$ Reed, Toward Freedom, 5.
} 
social scientists, and policymakers framed and responded to black social issues during this period.

Because they failed to consider the political-economic underpinnings of black inequality, many blacks' economic status in the postwar era remained dire. While America's middle class grew in the years after World War II, many blacks experienced a decline in their economic status due to postwar recessions and a loss of jobs through automation. By the 1960s, the black unemployment rate was more than double that of whites. ${ }^{30}$ Federal housing policy also contributed to blacks' bleak economic status. Up until it was outlawed by the 1968 Civil Rights Act, the Federal Housing Administration (FHA), which was a federal agency created by the 1934 National Housing Act to promote home ownership, encouraged real estate investors to practice redlining, which denied mortgage loans to inner-city blacks on the basis that they constituted a high financial risk and would reduce property values in white-occupied residential areas. This made it difficult for them to relocate to the suburbs where good jobs were located. ${ }^{31}$ These conditions caused many poor urban blacks to be concentrated in cities where they had limited job prospects. $^{32}$

President Kennedy grew concerned that such a high concentration of poor African Americans in urban areas would lead to an increase in delinquency and violence. Therefore, he directed his efforts toward establishing programs that centered on education, job training, and youth empowerment. One such program was New York’s Mobilization for Youth, which was

\footnotetext{
${ }^{30}$ Hinton, From the War on Poverty, 28.

${ }^{31}$ Keeanga-Yamahtta Taylor, Race for Profit: How Banks and the Real Estate Industry Undermined Black Homeownership (Chapel Hill: University of North Carolina Press, 2019), 31-37.

${ }^{32}$ Hinton, From the War on Poverty, 29.
} 
established in 1961 and offered job training and social services to the city's black and Latino residents. $^{33}$

A problem with the Kennedy administration's programs is that they assumed that the social issues blacks faced were an outgrowth of their supposed pathological behavior rather than structural forces. Historian Elizabeth Hinton explains how the federal government's tendency to create programs to redress poor blacks' supposed behavioral deficiencies during this period "removed fundamental socioeconomic change from the domestic policy agenda" and "aimed to change the psychological impact of racism within individuals rather than the impact of the long history of racism within American institutions." ${ }^{34}$ Using such an approach to deal with these issues ensured that they would worsen over time.

While the Kennedy administration initiated federal programs geared at targeting black delinquency, the Johnson administration's programs focused on black poverty. The main architect of Johnson's antipoverty programs was Daniel Patrick Moynihan. ${ }^{35}$

As previously mentioned, Moynihan was one of the earliest social scientists to link African Americans to the underclass in his influential 1965 study The Negro Family. Building largely on E. Franklin Frazier's research on black families, Moynihan argued that black poverty could be attributed to a "tangle of pathology," which he described as a set of cultural characteristics specific to African Americans that encouraged conditions like unemployment, dependency, and single-parent, matrifocal households. His analysis of black poverty was informed by his embrace of what Reed has called "institutional structuralism," which was a

\footnotetext{
${ }^{33}$ Kennedy's anti-delinquency programs were developed by his Committee on Juvenile Delinquency and Youth Crime. Staffed by prominent social scientists like Daniel Patrick Moynihan, Richard Cloward, and Lloyd Ohlin, the Committee foreshadowed the role that social scientists would play in shaping federal policy for poor minorities in the late $20^{\text {th }}$ century. See Hinton, $36,39$.

${ }^{34}$ Hinton, From the War on Poverty, 31.

${ }^{35}$ Hinton, From the War on Poverty, 57.
} 
framework that attributed poverty to group culture rather than political economy, and therefore identified acculturation as the crucial remedy to economic inequality. ${ }^{36}$

Consequently, many of the Great Society's programs reflected Moynihan's analysis of black poverty. Johnson's Community Action Programs are a case-in-point. Created by the Economic Opportunity Act of 1964, these programs "brought the methods employed by Mobilization of Youth and other juvenile delinquency demonstration projects of the Kennedy years to the national level," as one historian put it. ${ }^{37}$ Keeping true to Moynihan's analysis, they targeted black poverty not by addressing blacks' lack of access to resources that would allow for economic stability, such as access to jobs that paid a living wage and childcare resources, but by attempting to alter blacks' behavior. The Job Corps, for instance, offered job training to poor people between the ages of sixteen and twenty-one while the Work Experience Program aided "“unemployed fathers and other needy persons"” in gaining the "“capability for self-support or personal independence." $" 38$

While the Great Society reflected the federal government's growing optimism in preventative programs and their ability to eradicate black poverty, many had come to believe that black social pathology had reached a point of no return. This can be seen by looking at the media coverage on the 1965 Watts Riot. Though the riot started as a civil dispute between the LAPD and a black family, many periodicals saw it as evidence of a growing black pathology and the Great Society's inability to suppress it. ${ }^{39}$ Building off Moynihan's analysis, the Wall Street Journal cited the "'spreading disintegration of the Negro family" as a major cause of the riot.

\footnotetext{
${ }^{36}$ Reed, "Why Moynihan Was Not So Misunderstood at the Time."

${ }^{37}$ Hinton, From the War on Poverty, 50.

${ }^{38}$ Hinton, From the War on Poverty, 50-51.

${ }^{39}$ Hinton, From the War on Poverty, 64, 75.
} 
The riot also left the New York Times to conclude that the "“worst areas of Negro urban poverty have seemed oblivious"” to Johnson's antipoverty programs. ${ }^{40}$

Regardless of how the press viewed the riot, federal policymakers continued to stress the importance of discouraging black social pathology via preventative programs. While Hinton observes that they "acknowledged the socioeconomic conditions that precipitated the riot," they tended to focus on demographic indicators like single-parent households and illegitimacy as possible causes. Consequently, they proposed the development of programs that would provide African Americans with “"opportunities' for conforming [their] behavior.” One federally-funded mentorship program in South Carolina, for instance, sought to curtail violence among AfricanAmerican youth by providing them with male role models. ${ }^{41}$

While the Johnson administration invested in preventative programs, it also supported punitive measures for curtailing black crime and violence, which were advanced by the Nixon administration. ${ }^{42}$ In 1970, for instance, Nixon pushed for the passage of the District of Columbia Court Reorganization Act of 1970, which called for longer sentences for violent, repeat offenders. ${ }^{43} \mathrm{He}$ also initiated the "long range master plan," which expanded the American prison system for a period of 10 years. ${ }^{44}$

\footnotetext{
${ }^{40}$ Hinton, From the War on Poverty, 75 . Moynihan made a similar observation in his research on black families. In a 1965 Daedalus article, he suggests that black pathology had worsened to such a point that measures that would have proven effective in suppressing it in the past, like job availability, might not work in 1965: "It would be troubling indeed to learn that until several years ago employment opportunity made a great deal of difference in the rate of Negro dependency and family disorganization, but that the situation has so deteriorated that the problem is now feeding on itself-that measures which once would have worked will hence forth not work so well, or work at all." See Daniel Patrick Moynihan, "Employment, Income, and the Ordeal of the Negro Family," Daedalus 94, no. 4 (1965): 768.

${ }^{41}$ Hinton, From the War on Poverty, 77.

${ }^{42}$ Some of the Johnson administration's punitive policies included the Law Enforcement Assistance Act of 1965 and the Safe Streets Act of 1968, both of which provided federal support to local crime control measures. See Hinton 14, 56-57.

${ }^{43}$ Hinton, From the War on Poverty, 156.

${ }^{44}$ Hinton, From the War on Poverty, 164.
} 
Broad changes in America's economy in the 1970s ensured that Nixon's efforts to redress black crime and violence would not have much effect. With deindustrialization, for instance, a burgeoning information service economy started to displace the industrial economy. Globalization also assisted in the decline of America's industrial economy, as many multinational corporations began to outsource their manufacturing jobs to Third World countries to bypass labor unions and federal minimum wage laws. These developments had a disproportionate effect on working-class African Americans, who were overrepresented in the industrial sector and who lacked the education and training necessary to obtain new jobs offered by the service economy. As a result, many of them were restricted to urban areas riddled with poverty and unemployment. ${ }^{45}$

As deindustrialization and globalization ravaged black urban areas, social scientists in the 1980s sought to understand why poverty persisted in these areas. Rather than looking at the structural transformation of the U.S. economy's disproportionate impact on African Americans, many looked at Johnson's Great Society. This rationale served as the basis for Charles Murray's 1984 book Losing Ground. Murray argued that Johnson's policies had failed to eliminate poverty in urban areas because it encouraged individuals to stay on welfare rather than creating incentives for them to look for jobs. He further explained that this encouraged black pathology, since it made "[u]nemployment, illegitimacy, crime, and welfare dependency...more rational [and] bred the kind of bad behavior that fed on itself and became pathological." 46

Social scientists were not the only ones who shaped underclass ideology during this period. Journalists also played an important role in this regard. While social scientists looked at

\footnotetext{
${ }^{45}$ Michelle Alexander, The New Jim Crow: Mass Incarceration in the Age of Colorblindness (New York: New Press, 2011), 50.

${ }^{46}$ Connor, Poverty Knowledge, 248.
} 
poverty in their research on the underclass, Alice O' Connor notes that it "was neither a necessary nor sufficient condition" for journalists describing the underclass; "deviant behavior was. ${ }^{97}$ Ken Auletta, a journalist for The New Yorker, did more than any other journalist to popularize this view of the underclass. In his 1982 book The Underclass, for instance, Auletta measured the underclass strictly in terms of behavioral and moral deprivation. He classified them as welfare recipients, violent criminals, drug abusers, and high school dropouts. ${ }^{48}$

Murray's and Auletta's writings on the underclass signaled the rise of neoliberalism. Neoliberalism is a political, economic, and social ideology that began to gain traction in American society in the 1980s. Rather than stress the federal government's role in creating programs to alleviate poverty, crime, illegitimacy, and other issues, neoliberalism instead called for the government to enforce "majoritarian values" via punitive measures as a solution to these issues. For example, limiting single mothers' access to financial support and passing harsh sentencing laws to discourage illegitimacy and crime, respectively, were both facets of neoliberalism that enjoyed broad bipartisan support in the $1990 \mathrm{~s} .{ }^{49}$ It is hardly surprising, then, that individuals like Murray and Auletta were seen in tandem with the burgeoning neoliberal consensus in the 1980s, since both they and neoliberalism tended to link society's problems to individuals' moral shortcomings rather than broader structural issues.

Underclass ideology complimented Reagan's neoliberal approach to governance. Like other conservatives of his era, Reagan embraced the idea that many of society's problems stemmed from the federal government's tendency to encourage social pathologies among poor

\footnotetext{
${ }^{47}$ Connor, Poverty Knowledge, 267.

${ }^{48}$ Ken Auletta, The Underclass (New York: Random House, 1982), xvi.

${ }^{49}$ Adolph Reed, Jr, "Introduction," in Without Justice For All: The New Liberalism and Our Retreat From Racial Equality, ed. Adolph Reed, Jr. (Colorado: Westview Press, 1999), 2.
} 
minorities via welfare programs. Therefore, he sought out more strident measures as solutions to these issues, like the War on Drugs. While Reagan declared a "war on drugs" during a 1982 press conference, his efforts to double down on drug use intensified during the mid-1980s, when crack-cocaine exploded on the American scene. Rather than invest in drug prevention programs, Reagan instead called for draconian legislation that would target sellers and users of crack, a drug that tended to be associated with blacks and Latinos. One example is the Anti-Drug Abuse Act of 1986, which included harsh mandatory sentencing for those who sold crack. ${ }^{50}$

Neoliberalism and underclass ideology also affected Reagan's views on black families, which were clearly expressed in his radio address on welfare reform in 1986. Speaking on "welfare poor" families living in the inner cities, Reagan argued that social welfare programs exacerbated poverty by "[rupturing] the bonds holding poor families together." He explained that these types of families were broken because such programs encouraged mothers to stay single and unwed in exchange for benefits. He also said that these programs usurped the role of the father, denying them the right to be breadwinners. ${ }^{51}$

Perhaps nothing captures Reagan's views on the "welfare poor" better than his use of the "welfare queen" trope. While the term was first used by journalists in the 1970s, it began to be widely used in political debates about welfare in the 1980s. The "welfare queen" described single mothers who refused to work and relied on the state for financial security. Such a figure represented dependency and illegitimacy, since the more children she had out-of-wedlock guaranteed additional support from the state. In speeches, Reagan often referred to a "“Chicago welfare queen" who had "80 names, 30 addresses, 12 Social Security cards," and whose "tax-

\footnotetext{
${ }^{50}$ Alexander, The New Jim Crow, 53.

${ }^{51}$ Ronald Raegan, "Radio Address to the Nation on Welfare Reform," The American Presidency Project, February 15, 1986, accessed June 18, 2020, https://www.presidency.ucsb.edu/documents/radio-address-the-nation-welfarereform- 0 .
} 
free income alone is over $\$ 150,000 .{ }^{\prime \prime 52}$ Though he never mentioned race, many commentators took the welfare queen to be black, since welfare dependency tended to be associated with single, African-American mothers at this time.${ }^{53}$ Stating it plainly, Michelle Alexander asserts that "“welfare queen' became a not-so-subtle code for 'lazy, greedy, black ghetto mother."”54

Conservative Republicans like Reagan were not the only group of politicians who embraced neoliberalism. By the mid-1980s, liberal Democrats had also started to align themselves with the neoliberal consensus, which was indicative of the new direction their politics were taking by this period. Since the New Deal, liberal Democrats tended to support policies that favored "special interests" groups like women, the LGBTQ community, the working class, the poor, and minorities. Yet in the face of a political culture that was increasingly shifting rightward, many Democrats came to believe that minimal government and traditional values like personal responsibility and hard work were the solutions to many of these groups' problems, especially the latter two. ${ }^{55}$

It is within this political context that the Democratic Leadership Council (DLC) was formed. Founded in 1985 in the wake of the Democratic loss in the 1984 presidential election, the DLC was comprised of Democrats that would become key players on the national political stage in the 1990s, such as Al Gore and Bill Clinton. Believing that their commitment to "special

\footnotetext{
${ }^{52}$ Quoted in Alexander, The New Jim Crow, 49.

${ }^{53}$ Connor, Poverty Knowledge, 253.

${ }^{54}$ Alexander, The New Jim Crow, 49. For more discussion on the "welfare queen" trope, see Paula Giddings, "Where Do We Go From Here," Essence (EBSCOhost) 27, no. 5 (September 1996): 80, accessed May 19, 2020, https://edsb-ebscohost-com.libproxy.lib.ilstu.edu/eds/detail/detail?vid=6\&sid=0244ecd7-20db-4200-baa4-5b8251655510\%40p dc-v-sessmgr06\&bdata=JnNpdGU9ZWRzLWxpdmUmc2NvcGU9c210ZQ\%3d\%3d\#AN=9609042502\&db=ulh, Deborah Grey White, Too Heavy a Load: Black Women in Defense of Themselves, 1894-1994 (New York: W.W. Norton \& Company, 1999), 241, Ange-Marie Hancock, The Politics of Disgust: The Public Identity of the Welfare Queen (New York: New York University Press, 2004), Ann Marie Smith, Welfare Reform and Sexual Regulation (Cambridge: Cambridge University Press, 2007), and Julilly Kohler-Hausmann, "Welfare Crises, Penal Solutions, and the Origins of the "Welfare Queen," Journal of Urban History 41, no.5 (2015).

${ }^{55}$ Adolph Reed, Jr., "Introduction," 1-2.
} 
interests" had alienated the Party from its white, Protestant, middle-class constituency, many in the DLC began to shift the Party rightward in terms of how it dealt with minorities. Personal responsibility, hard work, law and order, and family values became common prescriptions for issues that seemed to plague poor people of color. While the DLC helped to shift Democrats (now called "New Democrats") to the right, Clinton, who chaired the DLC from 1990-1991, would do more than any other politician to push its agenda to the center of the Democratic Party platform during his presidency. ${ }^{56}$

During his 1992 campaign and presidency, Bill Clinton often showed how underclass scholars had a profound influence on his thinking about poor minorities. Perhaps one scholar who influenced his thinking more than any other was William J. Wilson. A social democrat and sociologist, Wilson ushered in new ways of understanding the black urban underclass. In his magnum opus The Truly Disadvantaged, he departed from underclass orthodoxy by highlighting the role that economic forces played in its development. He argued, for instance, that joblessness among poor urban blacks was largely a result of deindustrialization rather than a "culture of poverty." ${ }^{57}$ Despite this, Wilson still conformed to many underclass notions in his text. For one, he argued that the outmigration of working- and middle-class blacks from the inner city to the suburbs starting in the 1970s deprived poor blacks of "'social buffers"' (i.e. institutions and working- and middle-class families) that had traditionally served to counter long-term joblessness, crime, and welfare dependency by providing a check on behaviors that he believed encouraged such conditions, suggesting that the cure for such social ills was partially rooted in

\footnotetext{
${ }^{56}$ Philip A. Klinkner, "Bill Clinton and the Politics of the New Liberalism," in Without Justice For All: The New Liberalism and Our Retreat From Racial Equality, ed. Adolph Reed, Jr. (Colorado: Westview Press, 1999), 13-15.

${ }^{57}$ William J. Wilson, The Truly Disadvantaged: The Inner City, the Underclass, and Public Policy, $2^{\text {nd }}$ ed. (Chicago: University of Chicago Press, 2012), 41-46.
} 
behavior. ${ }^{58}$ Echoing Moynihan, Wilson also identified single-parent, female-headed households as a major impetus of poverty and welfare dependency among poor blacks in urban areas. ${ }^{59}$

Overall, Wilson's text is important not only because it signaled bipartisan support for underclass ideology, but also because it anticipated the direction that Clinton and many others would take on issues like crime and dependency during his tenure as president.

Clinton expressed a commitment to being tough on crime even before his presidency. This was partially motivated by Michael Dukakis's disastrous run for president in 1988. During the race, Willie Horton, a black convicted felon, assaulted a man and raped his wife while on a furlough. Dukakis's opponent, George. H.W. Bush, used the incident to portray Dukakis, who was a known supporter of the furlough program, as being soft on crime, which helped Bush win the presidency. Realizing that moderation on the crime issue was politically disastrous, Clinton flew out to his home state of Arkansas in 1992 to oversee the execution of Ricky Ray Rector, a mentally-challenged black man. Hoping to distance himself from soft-on-crime Democrats like Dukakis, Clinton remarked after the execution that "I can be nicked a lot, but no one can say I'm soft on crime." 60

In an effort to reduce crime, Clinton urged Congress to pass an anti-crime bill during his State of the Union Address on January 25, 1994. Drawing on neoliberal themes like minimal government, he explained why passing the bill was urgent: "Our problems go way beyond the reach of Government. They're rooted in the loss of values, in the disappearance of work, and the breakdown of our families and communities."

\footnotetext{
${ }^{58}$ Wilson, The Truly Disadvantaged, 56.

${ }^{59}$ Wilson, The Truly Disadvantaged, 26-29, 71-72.

${ }^{60}$ Alexander, The New Jim Crow, 54. Quoted on 56.

${ }^{61}$ Quoted in Carter, Brother Bill, 117.
} 
One of the bill's provisions called for an increased police presence in black urban areas. It provided funding to hire former servicemen and women as police officers. This measure seemed to have a positive effect on crime reduction. According to the Department of Justice, violent crime in these areas decreased during the Clinton years. Historian Daryl Carter, however, argues that this provision contributed to an increased rate of black male incarceration, since it provided officers with an opportunity to arrest black men without just cause. ${ }^{62}$

Another provision kept inmates from receiving Pell Grants. While the Higher Education Act of 1965 provided financial assistance to college students, it did little to provide that same assistance to inmates. The Pell Grant Program alleviated this oversight by funding inmates' education while they were incarcerated. With it being repealed, however, many black inmates were unable to receive an education, which limited their prospects for employment upon being released. This encouraged many to turn to the illicit economy and therefore increased their chances of becoming repeat offenders. ${ }^{63}$

Black males' recidivism added fuel to the bill's three-strike provision, which was perhaps its most highly publicized. The provision carried a minimum life sentence for anyone convicted of violent or drug-related crimes three or more times. Because black men were overrepresented among individuals who committed these crimes, it ensured that they would be disproportionally affected by it. ${ }^{64}$

Aside from its more punitive provisions, the crime bill also included preventative programs that were aimed at curtailing violent, criminal behavior. The Midnight Basketball League, for instance, funded basketball courts for at-risk urban youth of color. It was believed

\footnotetext{
${ }^{62}$ Carter, Brother Bill, 114.

${ }^{63}$ Carter, Brother Bill, 114.

${ }^{64}$ Carter, Brother Bill, 114-115.
} 
that such a measure would encourage youth to invest their time and energies in recreational activities rather than committing violent acts or joining gangs. This measure, however, was met with opposition from conservatives in Congress, many of whom believed that such programs failed to curtail crime. As a result, the funding for the program was reduced in the final bill. ${ }^{65}$ While the program reveals how committed politicians were to finding behavioral solutions to issues like crime, the reduction of its funding is indicative of how repudiated preventative programs had become by this period.

Strong black support was important to the bill's passage. Many were split on the provisions in the bill: some supported its punitive measures while others endorsed its preventative programs. Daryl Carter argues that many African Americans were receptive to neoliberalism, and therefore welcomed harsh measures they felt could curb violent behavior among poor urban blacks. ${ }^{66} \mathrm{He}$ also explains that those who supported the latter measure saw the bill as a compromise: while they did not support its punitive measures, they supported it regardless because it offered some funding for preventative programs. ${ }^{67}$

Many African-American politicians saw the bill's draconian measures as an ideal solution to black crime. They argued that tough-love policies were needed to effectively suppress crime in black urban areas, which was an issue they believed was beyond the scope of preventative programs. Ten black mayors pledged their support for the bill. One of the mayors, Kurt Schmoke, argued that the bill could "'send a signal to black perpetrators that if there is evil

\footnotetext{
${ }^{65}$ Carter, Brother Bill, 118-119.

${ }^{66}$ Carter, Brother Bill, 121.

${ }^{67}$ Carter, Brother Bill, 122.
} 
manifested by actions taken by individuals who choose to prey upon our residents that that evil will be responded to quickly and correctly.",68

Their support of the crime bill was indicative of a consensus that African Americans had about their poor urban brethren. Many of them had come to believe that violence in poor black urban areas had grown to epidemic proportions, and therefore welcomed federal assistance in subduing it. In keeping with underclass notions about black violence, many argued that violence in these areas was an outgrowth of innate pathologies rather than economic forces. An article written by Gwen Ifill, an African-American journalist, is telling on this point: "Representative Charles B. Rangel, the New York Democrat who has been pressing the Administration to spend more time addressing narcotics and crime, said the speech touched a chord in the black community. We have not spoken out about the cancers we have in our own bodies... But the violence has reached a point where we need help." 69

Aware of blacks' embrace of underclass ideology, Clinton sought to gain support for his crime bill by reaching out to his African-American constituency. Shortly after his initial crime bill was rejected by Congress, he traveled to a black church in Maryland to ensure its congregants of the bill's benefits to black communities. He attempted to garner support by playing on their fears of a growing black underclass and its threat to their communities: "These are children in the church who have been gunned down: I know it. The least we can do is help you to be protected. The least we can do is put people on the streets who cannot only catch

\footnotetext{
${ }^{68}$ Quoted in Larry Elder, "If Tough Anti-Drug Laws are 'Racist,' Blame Black Leaders," Winnipeg Sun (Nexis Uni), June 18, 2018, accessed May 19, 2020, https://advance-lexis-com.libproxy.lib.ilstu.edu/api/document?collection= news\&id=urn:contentItem:5SKD-RWK1-DYG6-1227-00000-00\&context=1516831.

${ }^{69}$ Quoted in Carter, Brother Bill, 120.
} 
criminals but prevent crime as good law enforcement officers. The least we can do if people are totally hopeless is to get them out of your hair so they won't be bothering you."70

Clinton's pandering to black churches proved effective. Many African-American clergymen came out in support of the bill. Pastors from various churches wrote a statement in support of the bill, stating that "while we do not agree with every provision in the crime bill, we do believe and emphatically support the bill's goal to save our communities, and, most importantly, our children." 71

Blacks did not unilaterally support the bill's strident measures. Many black politicians in Congress felt that the initial bill did not provide enough financial support for preventative measures. Perhaps no one group expressed greater frustration than the Congressional Black Caucus (CBC). The $\mathrm{CBC}$ is a political organization made up of black members of Congress. Founded in 1971, its goal is to support legislation that is favorable to African Americans. While the Caucus originally voted against the bill because Congress dropped the Racial Justice Act from it, it ended up voting for it because it contained an extension of the preventative measures members favored. ${ }^{72}$ This shows that while black attitudes about the bill were nuanced, African Americans, like many others, believed that issues like crime could be solved by shaping behavior rather than addressing broader structural issues.

Despite some initial rough patches, the Violent Crime Control and Law Enforcement Act passed in late August 1994. At the official signing of the bill in September of that year, Clinton outlined how its provisions would be implemented while invoking neoliberal themes like

\footnotetext{
${ }^{70}$ Quoted in Carter, Brother Bill, 121.

${ }^{71}$ Quoted in Carter, Brother Bill, 121.

${ }^{72}$ The Racial Justice Act was a provision originally included in the anti-crime bill that was designed to protect African Americans from being unfairly targeted by the bill's more punitive provisions. Believing that the provision provided an "unfair privilege" to minorities, both Congressional Democrats and Republicans had it dropped from the final bill. See Carter, Brother Bill, 103-109, 122.
} 
personal responsibility, family values, and the importance of community. ${ }^{73}$ While he does not specifically mention race, the fact that he expressed his position on crime by overseeing the execution of a black male, embraced the same law-and-order rhetoric that Republicans used to criminalize black males, and sought to exploit black fears of a violent black underclass suggest that the bill was meant to target poor people of color who lived in urban areas. Yet he was not alone: blacks who were advocates of either soft or harsh prevention measures also saw the bill as a way of reducing violence and crime in black urban areas. Underlying their support was a belief that these individuals constituted a violent growing underclass whose behavior needed to be corrected.

Much like his stance on crime, Clinton's attitudes about welfare reform were the product of underclass ideology. Much of his thinking on the matter seemed to come from liberal social scientists like David Ellwood, who had begun to shape policy debates about the issue in the 1980s. Ellwood, an economist and professor at Harvard's John F. Kennedy's School of Government who later served as Clinton's Assistant Secretary for Planning and Evaluation, proposed several solutions to what he saw as a dependency crisis among black, long-term welfare recipients. In his 1988 book Poor Support, for instance, Ellwood suggested that the federal government should cut off welfare benefits to recipients after two years while easing their transition into the workforce with job training programs. He also called for stricter child support laws for absent fathers. ${ }^{74}$ Time limits on welfare (which became known as the popular slogan “two years and you're off”), fostering job preparedness, and enforcing familial norms were defining aspects of bipartisan welfare reform measures during the Clinton years.

\footnotetext{
${ }^{73}$ Wolf Blitzer, "Text of Crime Bill Signing Ceremony," CNN (Nexis Uni), September 13, 1994, accessed May 19, 2020, https://advance-lexis-com. libproxy.lib.ilstu.edu/api/document?collection=news\&id=urn:contentItem:3TD8YWW0-0029-54VS-00000-00\&context=1516831.

${ }^{74}$ Conner, Poverty Knowledge, 253, 255, 285.
} 
Even before he became president, Clinton was shown to be an advocate of welfare reform. During his tenure as governor of Arkansas, for instance, he called for a "new contract" between welfare recipients and the federal government, where "“[r]ecipients would commit to strive for independence in return for the benefits, and the government would commit to help them." He also established a workfare program in the state that helped prepare recipients to transition from welfare to work by providing them with job training skills. Lastly, he supported a 1988 welfare reform law that required teen mothers to stay in school and live at home with their parents to receive benefits. ${ }^{75}$

Clinton initially tried to curtail welfare among the "working poor" by expanding the Earned Income Tax Credit (EITC). Created in 1976, the EITC is a tax credit that is awarded annually to moderate-to-low income taxpayers with children. Its purpose was to create incentives for low-paid, working-class people to work and sustain their families. The measure received support from both New Democrats and conservative Republicans, since it encouraged the working poor to stay off welfare and maintain their families. It was also appealing because it ensured that financial rewards went to working people with strong family values (the "deserving poor") rather than poor, lazy blacks who had weak family structures (the "undeserving poor"). ${ }^{76}$ While Clinton pushed for welfare reform as early as 1992, he did not make any legislative strides toward "ending welfare as we know it" until 1995. His administration was dealing with several other issues in the interim. As alluded to earlier, Clinton spent much of his first term pursuing punitive crime prevention measures. The economy was also a major concern for Clinton. Tax cuts and a massive defense budget had contributed to a major recession, and Clinton spent his first few years in office trying to resolve it. Finally, health care reform weighed

\footnotetext{
${ }^{75}$ Carter, Brother Bill, 171.

${ }^{76}$ Carter, Brother Bill, 181; Conner, Poverty Knowledge, 286-287.
} 
heavily on Clinton's mind during these years. By 1993, at least 15\% of America's population was without health coverage. ${ }^{77}$

He began to actively pursue welfare reform, however, when Republicans gained control of Congress in 1995. As Republicans became the majority in Congress for the first time in 40 years, Clinton felt that it was necessary to balance his agenda with that of Congress's, the latter of which included cutting welfare. Congressional Republicans had begun to double down on welfare reform as early as 1991, when 40 from the House formed the Wednesday Group, a caucus that called for mandatory work and time limits on welfare. Republicans also published the "Republican Contract with America" in 1994, which also called for welfare reform along the same lines. ${ }^{78}$

To push their welfare reform agenda, Congressional Republicans drafted two welfare reform bills in 1995 and 1996. Each bill contained a provision that repealed Aid to Families with Dependent Children (AFDC) and replaced it with the Temporary Assistance to Needy Families (TANF). AFDC was a federal program that was created by the Social Security Act of 1935. Its goal was to provide financial assistance to low-income families. Many Republicans and New Democrats called for its repeal because they believed it incentivized poor people to stay out of work. ${ }^{79}$ Thus, both parties supported TANF, which placed a 5-year limit on financial assistance that individuals and their families could receive from the federal government. State governments, however, could choose to increase or decrease this limit. It also required recipients to find work two years after first receiving benefits. ${ }^{80}$ It was believed that such legislation would drive people

\footnotetext{
${ }^{77}$ Carter, Brother Bill, 186-187.

${ }^{78}$ Carter, Brother Bill, 182.

${ }^{79}$ Carter, Brother Bill, 170, 182-183.

${ }^{80}$ Nailah R. Brock, "African Americans and Welfare Time Limits: Comparative Analysis of State Time Limit Policies under the Personal Responsibility and Work Opportunity and Reconciliation Act of 1996," Journal of Black Studies 39, no. 6 (2009): 962-963.
} 
to get off welfare and find work, but this assumption belied the fact that many people were on welfare not because they were dependent on the government, but because there were a lack of accessible jobs that paid a living wage.

Eliminating dependency was not the only goal of welfare reform. Politicians also hoped that it would reinforce cultural values that were popular during this period, such as the development of the two-parent household. Republicans and New Democrats believed that welfare was a major contributor to single motherhood because it encouraged mothers to stay single and unmarried in order to receive benefits from the state. Therefore, they hoped that reform would “"discourage illegitimacy and teen pregnancy by prohibiting welfare to minor mothers and denying increased AFDC for additional children." ${ }^{\prime 81}$

Like Republicans and other New Democrats, Clinton supported the repeal of AFDC because he believed that it exacerbated dependency and family dissolution among poor people. He often cited underclass scholars in his defense of welfare reform. In a 1993 NBC interview, for instance, Clinton praised Murray for his analysis of the welfare system and its effects on poor people:

He did the country a great service. I mean, he and I have often disagreed, but I think his analysis is essentially right... ${ }^{82}$ There is no question that... if we reduced Aid to Families with Dependent Children, it would be some incentive for people not to have dependent children out of wedlock ... [O]nce a really poor woman has a child out of wedlock, it almost locks her and that child into the cycle of poverty which then spins out of control further. ${ }^{83}$

\footnotetext{
${ }^{81}$ Quoted in Carter, Brother Bill, 182.

${ }^{82}$ Quoted in "Welfare Reform: Clinton, Gore Both Give Quayle His Due," The Hotline (Nexis Uni), December 6, 1993, accessed May 19, 2020, https://advance-lexis-com.libproxy.lib.ilstu.edu/api/document?collection=news\&id= urn:contentItem:3SJJ-3N40-004B-G1KV-00000-00\&context=1516831.

${ }^{83}$ Quoted in William Claiborne, "Unwed Mothers Lift Welfare Costs; Clinton Seeks Way to Cut Rate of Out-ofWedlock Births Among Young," The Washington Post (Nexis Uni), December 9, 1993, accessed May 19, 2020, https://advance-lexis-com.libproxy.lib.ilstu.edu/api/document?collection=news\&id=urn:contentItem:3S7T-7RD00088-P46F-00000-00\&context=1516831.
} 
Despite the bipartisan drive for welfare reform, the Clinton administration rejected the first two welfare reform bills proposed by the Senate in 1995 and 1996. Clinton reasoned that the two bills would exacerbate dependency, keep recipients from gaining job-related skills, and lead to drastic cuts in programs that working people depended on: "the House bill would actually make it harder for many people to get off and stay off welfare...It removes any real responsibility for states to help people gain the training and skills they need to get and keep jobs. It even cuts child care for working people struggling to hold down jobs and stay off welfare." ${ }^{84}$

Like Clinton, African-American politicians in Congress generally did not support Republican welfare reform measures. Of the 39 black members of Congress who voted on the proposed welfare reform bill of 1995, for example, only two voted in favor of it. Those who opposed it believed that the bill not only foreshadowed the end of the government's commitment to poor people in general but to African Americans in particular. ${ }^{85}$

This does not mean that blacks were monolithic in their views on welfare reform. Many supported it. A survey cited in a 1994 Los Angeles Times article showed that 70\% of blacks polled supported the more punitive aspects of welfare reform, including cutting off recipients after two years and requiring them to work. Political scientist Sharon D. Wright also explains that polls during the time show that black support for welfare reform was close to whites. ${ }^{86}$

Despite his initial rejections, Clinton eventually signed the Personal Responsibility and Work Opportunity Act of 1996. Alice O’ Connor cites the possible reasons why Clinton signed off on the punitive welfare reform act. For one, she explains that once Republicans gained control of Congress in 1995, Clinton was unable to pursue less punitive welfare reform

\footnotetext{
${ }^{84}$ Quoted in Carter, Brother Bill, 189.

${ }^{85}$ Carter, Brother Bill, 184-186.

${ }^{86}$ Carter, Brother Bill, 185-186.
} 
measures, and as a result signed the bill as a political compromise. She also argued that his eventual embrace of the bill grew out of his earlier commitment to welfare reform and his desire to "out-tough... Republicans" on the issue. ${ }^{87}$

Clinton declared his intent to "end welfare as we know it" during his 1992 presidential campaign. Yet he was hardly alone in undertaking such a task. While he worked to dismantle the welfare state through his reform efforts as governor, his expansion of the EITC, and his support of the AFDC's dissolution, social scientists and Republicans were just as instrumental in pushing through measures that would result in the Personal Responsibility Act. While social scientists like Ellwood proposed policy recommendations that would make it in the final bill, Republicans worked to get the legislation passed in Congress. New Democrats and African Americans were also pivotal to welfare reform, as they even supported its more punitive aspects. The driving rationale behind their support of welfare reform was the belief that welfare contributed to dependency and broken families among poor people of color, an idea that bears the imprint of underclass ideology.

\section{Conclusion}

As we have seen, the underclass is not simply a concept that developed in a vacuum. Rather, it is an ideology whose evolution was aided by social scientists, policymakers, and politicians who were trying to come to grips with the countless social problems that poor urban blacks faced in postwar America. While blacks had attained their civil rights, these actors predicted that they would face challenges in terms of their preparedness of being equal citizens. This is not to suggest that their attitudes about blacks made them racist in the pejorative sense of the term. Indeed, individuals like Kennedy and Moynihan were lifelong liberal Democrats who

\footnotetext{
${ }^{87}$ Connor, Poverty Knowledge, 286.
} 
were committed to the idea that blacks should have the same civil and legal rights as other American citizens. Yet their tendency to link blacks' lack of preparedness to culture and behavior caused them to ignore broader changes in the American economy that were the real cause of many of the social problems they faced. Such an oversight ensured that blacks would continue to feel the negative effects of these changes.

Conservative Republicans' embrace of underclass ideology during the Reagan years cannot be seen in isolation from political and economic developments that started in the late 1970s. As deindustrialization and globalization began to displace working-class African Americans from industrial jobs, crime, dependency, and other signs of "social pathology" started to become more common in black urban areas. Underclass scholars like Murray argued that the welfare state encouraged such antisocial behavior because it kept individuals (especially poor minorities) from seeking out jobs and building nuclear, two-parent families. Such a rationale went hand-in-hand with the emerging neoliberal consensus, which tended to attribute social ills to individuals' lack of personal responsibility and commitment to family and community. In this way, neoliberalism bolstered underclass ideology’s appeal to conservatives by complimenting and reinforcing many of the latter's central tenets.

Underclass ideology found bipartisan support during the Clinton years. This is not to suggest that it did not shape liberal Democrats' attitudes about the poor prior to the Clinton presidency. As Daryl Carter notes, Democrats like Alice Rivlin and Barbara Blum were members of an anti-welfare group known as the "working seminar" as early as 1986, which "linked welfare with behavioral dysfunction and dependency" rather than political economy. ${ }^{88}$ Yet it did not become a central facet of Democratic ideology until Clinton's election. Clinton

\footnotetext{
${ }^{88}$ Carter, Brother Bill, 179.
} 
drew on underclass ideology to advocate for draconian crime prevention and welfare reform measures that had a negative impact on poor people of color.

It was within such a political milieu, where underclass ideology had become "hegemonic," that black liberals began to change how they thought about black social issues. ${ }^{89}$ Whereas they would have been more likely to tie these issues to broader political and economic forces prior to the 1980s, by the 1990s, they, like their contemporaries, believed that such issues were rooted in blacks' supposed innate behavioral and cultural traits. As will be explored in more depth in the next chapter, for instance, Rev. Jesse Jackson sponsored a summit in early 1994 that sought to develop behavioral solutions to crime and violence in black urban areas. ${ }^{90}$ Even former president Barack Obama, who came of age as a politician during the Clinton years, has also shown to be influenced by underclass ideology. Arguing that blacks in urban areas are "trapped by their own self-destructive behaviors," Obama offered several prescriptions for solving the poverty dilemma in these areas in his book The Audacity of Hope, including discouraging women from having children out-of-wedlock and fostering responsible men. ${ }^{91}$

This black liberal embrace of underclass ideology laid the foundation for a conservative shift in African-American politics in the 1990s. Black liberals' belief in behavioral solutions to black social issues allowed black conservative factions like the Nation of Islam, who had also embraced similar ideas but remained on the fringes of black politics, to become a significant part of black politics by this period. Both black liberals and the Nation employed behavioral measures to challenge gangsta rap and its supposed exacerbation of these issues. Thus, black censorship is essential to understanding this shift.

\footnotetext{
${ }^{89}$ Adolph Reed, Jr, "Introduction," 1.

${ }^{90}$ Joint Center for Political and Economic Studies, "Political Trend Letter," FOCUS 22, no 2 (1994): 1.

${ }^{91}$ Barack Obama, The Audacity of Hope: Thoughts on Reclaiming the American Dream (New York: Random House, 2006), 399, 400, 402-403.
} 
CHAPTER II: BLACK LIBERAL REPONSES TO GANGSTA RAP, 1993-2000

In 1995, People magazine published a cover story on C. Delores Tucker and her involvement in the gangsta rap censorship movement. Tucker, who by then had been a part of the movement for two years, lamented about the negative effects that the genre supposedly had on African-American listeners. She recalled how her teenage nephew dropped out of high school and impregnated his girlfriend shortly after he started listening to the music. "'His behavior started changing,"” she said. "'He tore down his art on the walls and the album covers went up. He started doing everything [the rappers] do." ${ }^{, 92}$

This tendency to link African Americans' consumption of gangsta rap with antisocial behavior was not uncommon. Rather, it was reflective of a conservative political culture that had come to tie black social issues to pathology. By the 1990s, black liberals like Tucker had begun to disavow federal social service programs and instead put their faith in grassroot measures meant to redress blacks' supposed behavioral deficiencies. Whether they were aware of it or not, their attitudes were informed by a belief that crime, delinquency, dependency, poverty, and a host of other social issues were a result of blacks' (especially poor, urban blacks) moral shortcomings rather than economic changes and the federal government's growing indifference to poor people.

Therefore, it is not surprising that black liberals would seek out gangsta rap censorship as an avenue for resolving these issues. As the genre started to grow in popularity in the early 1990s, they started to speak out against what they perceived to be a correlation between its popularity among African Americans and their tendency to exhibit social pathologies like

\footnotetext{
${ }^{92}$ Patrick Rodgers and Rochelle Jones, "Gunning for Gangstas," People (EBSCOhost), June 26, 1995, accessed May 20, 2020, 105, http://libproxy.lib.ilstu.edu/login?url=https://search.ebscohost.com/login.aspx? direct=true\&db=f5h\& AN $=9506291586 \&$ site $=$ eds-live $\&$ scope $=$ site.
} 
criminal behavior and sexual promiscuity. Tucker, for instance, was a permanent fixture at rallies, corporate board meetings, and congressional hearings that dealt with the genre's impact on listeners. Others like Rev. Calvin O. Butts used his church as a bully pulpit to speak out against the genre and was a frequent commentator on talk shows and music programs that discussed the genre.

This chapter examines their responses to gangsta rap from 1993 to 2000. It looks at four related issues that the genre's opponents felt the genre had a role in promoting among its African-American audience: violence, crime, sexual promiscuity, and family disorganization. By 1993, black criminality and violence had become hot button issues among black liberals, and they were committed to using censorship as a means of suppressing them. They addressed several facets of these issues, including black-on-black violence, mass incarceration, violence against women, and urban violence. A common thread linking their criticisms of the genre in this vein and advocacy of censorship was a belief that it encouraged these conditions and that preventative measures that stressed behavioral readjustment were an essential remedy.

The chapter then looks at how censors responded to gangsta rap that sexually degraded black women. Arguing that such portrayals of black women ran counter to proper feminine behavior, censors sought to pursue strategies that would deter black girls from embracing the sexual stereotypes associated with the genre, like shoring up their morale.

Censors also explored the supposed connection between the genre and dysfunctional black families. In keeping with the conservatism of the times, censors generally traced social pathologies like growing teenage pregnancy rates, absent or unfit fathers, and unruly children to the breakdown of the black family. Their criticisms tended to eschew economic interpretations of 
inequality and its human toll and instead identified gangsta rap as a major contributor to social decay.

\section{Crime/Violence}

Motivated by concerns about the anti-crime bill's impact on black incarceration, several black politicians, religious leaders, civil rights leaders, and academics met at a Washington conference organized by Rev. Jesse Jackson’s Rainbow Coalition in January 1994 to develop alternative strategies for reducing violence and criminality in black urban areas. Many at the conference agreed that black-on-black violence and homicide were two issues that had to receive top priority if any serious measures to redress violence and crime were to be taken. Statistics presented at the conference reinforced the need for effective measures: according to FBI reports, 8,000 black men on average were murdered by other black men annually at a $90 \%$ rate. The reports also revealed that $60 \%$ of juveniles arrested on homicide charges in 1993 were AfricanAmerican males. ${ }^{93}$

In response, conference participants proposed several strategies to combat rising crime rates and violence in black communities. While many stressed the need for more jobs, others proposed developing mentorship programs. One such program was the Coalition's “Reclaim Our Youth" program, which would be aimed at remanding first-time offenders to mentors who would be trained in churches. For organizations like the Rainbow Coalition, the appeal of mentorship programs as a remedy to crime and violence was informed by a belief that these issues stemmed from blacks' behavioral deficiencies. As Rev. Graylan Ellis-Hagler lamented: “[f]or too long, churches have conducted their worship services, said their prayers, supported fellowship

\footnotetext{
${ }^{93}$ Joint Center, "Political Trend Letter," 1.
} 
societies, and closed their doors to the outside world...As a consequence of shutting out the world, an underclass has developed that has been invisible to the church. ${ }^{94}$

One participant who also stressed behavioral solutions to black crime and violence was Tucker. Up until the early 1990s, nothing in her career suggested that she would become a vocal critic of the genre. Born in Philadelphia in 1927 and raised in a Baptist household, Tucker attended Temple University but dropped out to open an employment agency for black southern migrants in the city. ${ }^{95}$ She first became politically active during the Civil Rights Movement and was later appointed Philadelphia's Secretary of State in 1971, becoming the first African American to hold the position. She helped found the National Political Congress of Black Women (NPCBW) in 1984, an organization aimed at increasing black women's representation in the federal government. She also became its national chair in $1992 .{ }^{96}$

Tucker spoke on the second day of the conference, which focused on violence against black women. During her speech, Tucker argued that gangsta rap encouraged black males to commit acts of violence against black women. She also suggested that there was a direct correlation between gangsta rap and rising homicide rates in black communities. Much of her criticism was directed towards Snoop Doggy Dogg's debut album Doggystyle, which was quickly becoming popular among black and white audiences. ${ }^{97}$

This was not the first time that Tucker addressed these issues. In 1992, she helped organize the NPCBW's Entertainment Commission with entertainers Melba Moore and Dionne Warwick, Billboard magazine writer Terri Rossi, and Von Alexander, its director. Tucker

\footnotetext{
${ }^{94}$ Joint Center, "Political Trend Letter," 1.

95“"C. Delores Tucker, 1927-2005,” The Journal of Blacks in Higher Education, no. 49 (Autumn, 2005): 59.

${ }^{96} J$ Jordan A. Conway, "Living in a Gangsta's Paradise: Dr. C. Delores Tucker's Crusade Against Gangsta Rap Music in the 1990s," (MA thesis, Virginia Commonwealth University, 2015), 13-14. The organization was later renamed the National Congress of Black Women (NCBW). See Conway, "Gangsta's Paradise," 14.

${ }^{97}$ C. Delores Tucker, "Violence Against Women," C-SPAN, January 6, 1994, 23:37-35:14, accessed May 20, 2020, https://www.c-span.org/video/?53577-1/violence-women.
} 
decided to form the organization after female secretaries and executives in the music industry

approached her with concerns about the sexist and misogynistic lyrics in gangsta rap. ${ }^{98}$ The

Commission had specific goals in mind:

(1) To seek to eliminate internal blockage in the industry that currently and most obviously prevents African-Americans from achieving equal opportunities as artists and decision-makers; (2) To mobilize African-Americans in the industry to join the struggle to resolve critical issues affecting African-American communities, particularly in the areas of education and health, where so many serve as role models and spokespersons; AND (3) To offer strategic suggestions and solutions for reshaping and maintaining positive images to preserve our dignity and heritage for our youth ... INSTEAD of continuously exposing our youth to negative media that distort their images of male/female relationships, undermine the stability of our families, communities and nation by encouraging violence, abuse and sexism as acceptable behaviors, and perpetuates the cycle of low self-esteem of African-American youth. ${ }^{99}$

While misogynistic lyrics were the main impetus for the Commission's decision to pursue censorship, it was also concerned with how rappers supposedly encouraged African Americans to commit violent, criminal acts. These claims were not entirely without merit. In 1992, for instance, Ronald Ray Howard, a 19-year-old African-American male, was convicted of shooting and killing a Huston state trooper during a traffic stop. During his trial, he told the jury that he was listening to Tupac Shakur's debut album 2Pacalyspe Now, which he claimed influenced him to commit the murder. His lawyer also argued that Howard was a "'rap addict who lived, breathed and worshiped"" the violent lifestyle portrayed in gangsta rap. ${ }^{100}$

The Commission was also concerned about how so many young African Americans looked up to rappers who committed violent acts. In 1993, for instance, Snoop was brought up on murder charges for his involvement in an altercation that resulted in the shooting death of a

\footnotetext{
${ }^{98}$ Judith Weinraub, “Delores Tucker, Gangsta Buster; She's Playing in Her Offensive Against Rap,” Washington Post (Nexis Uni), November 29, 1995, accessed May 20, 2020, https://advance-lexis-com.libproxy.lib.ilstu.edu/api/ document?collection=news\&id=urn:contentItem:3S7R-2N70-0088-P02P-00000-00\&context=1516831.

${ }^{99}$ Quoted in Conway, “Gangsta's Paradise,”15.

${ }^{100}$ Chuck Philips, “Rap Defense Doesn't Stop Death Penalty: 'The music affected me,' says Ronald Ray Howard. 'That's how it was that night I shot the trooper," Los Angeles Times, July 15, 1993, accessed May 20, 2020, http:// articles.latimes.com/1993-07-15/entertainment/ca-13309_1_ronald-ray-howard.
} 
young man. Tupac was also charged with shooting two off-duty police officers in Atlanta,

Georgia and sexually assaulting a young woman in a hotel room that same year. ${ }^{101}$

Concerned with the violent and criminal behavior associated with gangsta rappers and their music, the Commission reached out to Senators Cardiss Collins and Carol Moseley-Braun to organize congressional hearings that would assess the impact of gangsta rap on youth violence. ${ }^{102}$ The first of these hearings were held on February 11, 1994. Presided over by Collins, the hearing featured commentary from academics, journalists, and people involved in the television and the music industry. Tucker was one of the many speakers. In her testimony, she stressed that gangsta rap influenced black males to engage in self-destructive behavior that would lead them on the path to prison. To prove her point, Tucker read a letter from a Virginia prisoner who blamed his imprisonment on the genre:

Rappers... made it sound so good and look so real (that) I would drink and smoke drugs just like on the video, thinking that was the only way I could be somebody...My hood girls--became hoes and bitches. What's so bad is that they accepted it. You know why? Because they put themselves in the video, too, and the guns, money, cars, drugs, and men became reality. Look where this kind of thinking has gotten me...facing 25 years to life in jail. ${ }^{103}$

Tucker also made connections between gangsta rap and crime at the second hearing on February 23, 1994. Unlike many advocates of crime prevention during this period, Tucker used her testimony as an opportunity to highlight the crime bill's inability to effectively suppress

\footnotetext{
${ }^{101}$ Richard Harrington, "Guns N' Rappers: 3 Arrested In Shootings," Washington Post (Nexis Uni), November 3, 1993, accessed May 20, 2020, https://advance-lexis-com.libproxy.lib.ilstu.edu/api/document?collection=news\&id= urn:contentItem:3S7T-7XT0-0088-P12T-00000-00\&context=1516831; "Shakur Released On Bail After Sex Assault Charges," Jet (Nexis Uni), December 13, 1993, accessed June 21, 2020, https://advance-lexis-com.libproxy.lib.ilstu. edu/api/document?collection=news\&id=urn:contentItem:3SP2-6G60-006G-23N9-00000-00\&context=1516831. ${ }^{102}$ Conway, "Gangsta's Paradise," 26-27.

${ }^{103}$ C. Delores Tucker, "Testimony February 11, 1994 Dr. C. Delores Tucker National Chair National Political Congress of Black Women National Energy/Commerce Consumer Protection and Competitiveness Music Lyrics and Interstate Commerce," Federal Document Clearing House Congressional Testimony (Nexis Uni), February 11, 1994, accessed May 20, 2020, https://advance-lexis-com.libproxy.lib.ilstu.edu/api/document?collection=news\&id= urn:contentItem:3SJ4-NV20-0003-12RG-00000-00\&context=1516831.
} 
black crime. Describing the bill as a "short-term initiative," she urged Congress to adopt "long-term and preventative measures" for black crime by curtailing the sale of gangsta rap. She also expressed concerns that children who did not have positive role models were the most receptive to the genre's negative influences and would "trigger a crime wave of epidemic proportions." 104

To suppress the influence of gangsta rap on black youth, Tucker proposed that Congress create "private-public partnerships" that would be aimed at establishing boarding schools for atrisk black youth. She hoped that such schools would be modeled after Girard College in Philadelphia. Founded in 1848 by Stephen Girard, a French immigrant, Girard College was a boarding school that only initially admitted school-aged, poor white males, though the school became integrated in 1968. She explained that the proposed schools would have "'Youth-Town"” residential centers, which would have programs to prevent at-risk children from committing crimes and rehabilitation programs to help nonviolent first offenders. ${ }^{105}$

While Tucker's criticisms of gangsta rap hint at an embrace of underclass ideology, she often made it clear that it had a direct influence on her thinking about the genre. She often gave speeches where she discussed the deleterious effects of gangsta rap on African-American youth. In one of these speeches, Tucker quoted an article about the black underclass to make a case that the genre contributed to the growth of a violent black underclass: "'Soon, 14 million poor children will become 14 million unskilled uneducated, angry dangerous adults. There will not be enough jails, enough bullets, enough quick-fix federal programs. There will be them and an

\footnotetext{
${ }^{104}$ C. Delores Tucker, "Statement of C. Delores Tucker," in Shaping Our Responses to Violent and Demeaning Imagery in Popular Music: Hearing Before the Subcommittee on Juvenile Justice of the Committee on the Judiciary, United States Senate, One Hundred Third Congress, Second Session ... February 23, 1994, 13-14.

${ }^{105} \mathrm{C}$. Delores Tucker, "Remarks at the George H. Gallup International Institute Conference," Vital Issues: The Journal of African American Speeches 9, no. 4 (Winter 1999): 17.
} 
older, feebler generation increasingly dependent on us. They will blot out the sky, foul the air, make the water unfit to drink. They will steal tomorrow. They are time bombs." 106

Tucker was not the only figure who drew connections between gangsta rap and black violence. Another was Rev. Calvin O. Butts. Butts joined Harlem’s Abyssinian Baptist Church as a youth minister in 1972. He quickly became known for his activism, founding the Abyssinian Development Corporation in 1989, an organization that was geared toward community development in Harlem. He was also known for taking a stance against issues he felt lead to depravity among African-Americans. In 1992, for instance, he painted over billboards that advertised cigarettes and alcohol because he believed they intentionally targeted black neighborhoods. It is no wonder, then, that he would target gangsta rap, which, as one commentator said, "is consistent with the kind of mission [he] is on.",107

Butts garnered national attention when he tried to steamroll a pile of rap cassettes and CDs in front of his church in 1993. He did so as a protest to gangsta rap, which he felt did nothing to redeem African-American communities and portrayed blacks in a negative light. While many supported Butts's measure, others were opposed to it, arguing that whites who owned record companies and music video stations should be to blame for perpetuating negative images of African Americans. ${ }^{108}$

Butts's actions were partly motivated by a desire to reduce violence in black communities. Much like Tucker, Butts believed that gangsta rap was a central cause of growing black violence. Rarely did his criticisms of the genre include any acknowledgement of broader

\footnotetext{
${ }^{106}$ Tucker, "Remarks at George H Gallup," 16.

${ }^{107}$ Larry Olmstead, "From Powerful Pulpit, a Moral Warrior Takes Aim," New York Times (Nexis Uni), June 5, 1993, accessed May 20, 2020, https:// advance-lexis-com.libproxy.lib.ilstu.edu/api/document?collection=news\&id =urn:contentItem:3SC6-TN30-0024-J507-00000-00\&context=1516831.

${ }^{108}$ Clifford J. Levy, "Harlem Protest of Rap Lyrics Draws Debate and Steamroller," New York Times (Nexis Uni), June 6, 1993, accessed May 20, 2020, https://advance-lexis-com.libproxy.lib.ilstu.edu/api/document?collection= news\&id=urn:contentItem:3SC6-WM70-0024-J41R-00000-00\&context=1516831.
} 
economic trends as contributing factors in causing the violence. In 1993, for instance, a parentteacher association invited Butts to speak at a New York high school about the rise of violence among black youth. With "hardly a mention of poverty or joblessness," as one reporter noted, Butts proceeded to blame the rise of violence on gangsta rap. He then told parents that they should collaborate with schools and churches to "“[build] character and [teach] values"” as a way of deterring black children from violent behavior. ${ }^{109}$

Butts's and Tucker's calls to use schools and churches to curb antisocial behavior among black youth was not the only tactic black liberals employed to combat gangsta rap's supposed negative influence. Many also sought to counter its influence by steering black males away from deviant behavior. The New York Leadership Alliance is a case-in-point. The Alliance was a group started by prominent African-Americans, including radio personality Bob Law and New York Councilman Charles Barron. Its goal was to combat domestic violence and other forms of maltreatment of African-American women. ${ }^{110}$ As a testament to his commitment to shaping black men's behavior, who were thought to be the cause of such problems, Law served on the Executive Council of the Million Man March, an event that had the same goal in mind. ${ }^{111}$

Law, Barron, and others started the group in response to attacks in Central Park initiated by young men against women. One of those, in June 2000 after the Puerto Rican Day Parade, elicited great media attention. Many women told reporters that they were groped, sprayed with

\footnotetext{
${ }^{109}$ Somini Sengupta, “'Save Our Children;' Rev. Butts Speaks out Against Youth Violence,” Newsday (Nexis Uni), November 19, 1993, accessed May 20, 2020, https://advance-lexis-com.libproxy.lib.ilstu.edu/api/document? collection=news\&id=urn:contentItem:3SJD-N650-0024-44S1-00000-00\&context=1516831.

110“17th Arrest is Made in N.Y. Sex Attacks," Philadelphia Daily News (Nexis Uni), June 19, 2000, May 20, 2020, https://advance-lexis-com.libproxy.lib.ilstu.edu/api/document?collection=news\&id=urn:contentItem:451F-F0400191-11YM-00000-00\& context=1516831.

${ }^{111}$ Maulana Karenga, "The Million Man March/Day of Absence Mission Statement," in Million Man March/Day of Absence: A Commemorative Anthology: Speeches, Commentary, Photography, Poetry, Illustrations, Documents, eds. Haki R. Madhubuti and Maulana Karenga (Chicago: Third World Press, 1996), 141. The Million Man March will be discussed at length in the next chapter.
} 
water, and had their clothes torn off. At least 17 people were arrested in connection with the attacks. $^{112}$

Law and Barron believed that gangsta rap's portrayal of women was a major impetus for black involvement in the attacks. Naturally, they called for "'economic sanctions' against music companies producing rap music that denigrates women.'" Law believed that black men were susceptible to negative attitudes about women promoted in the genre, and therefore more likely to be violent towards them, because their communities lacked role models to offer them guidance on how to behave properly. He therefore asserted that the "challenge nonetheless remains for responsible black men to step up now and provide a model for what men and fathers should be." 113

While Bob and Law publicly condemned gangsta rap, individuals like Rev. Benjamin Chavis had a more positive outlook on the genre. A civil rights activist, Chavis gained national attention in the 1970 s as one of the Wilmington Ten, who were ten individuals accused of firebombing a white-owned grocery store in Wilmington, N.C. during a civil rights protest in 1971. In 1993, he assumed leadership of the NAACP, becoming the youngest person ever to do so. From the start, Chavis hoped to use his position to broaden the NAACP's appeal to diverse segments of the African-American community. One way he sought to do this was by embracing gangsta rap. ${ }^{114}$ For instance, he hosted a music forum where he declared that the organization would "fight for the right of rappers to rap about the hard realities of life in a society permeated

\footnotetext{
112" $17^{\text {th }}$ Arrest."

113، $17^{\text {th }}$ Arrest." It is worth mentioning that this incident was often seen in the context of the 1989 Central Park attacks, where four African-American teenagers and one Hispanic teenager were wrongfully accused and convicted of raping a white woman. Given this, Law's and Barron's concerns about black men's treatment of women seem understandable.

${ }^{114}$ Sonya Ross, "Chavis, NAACP Board Struggle Over Group's Direction," The Associated Press (Nexis Uni), April 12, 1994, accessed May 20, 2020, https://advance-lexis-com.libproxy.lib.ilstu.edu/api/document?collection=news\& id=urn:contentItem:3SJJ-5RN0-008G-74B2-00000-00\&context=1516831.
} 
by racial oppression and exploitation." He was also instrumental in getting Tupac nominated for a NAACP Image Award in 1994, a decision that the NPCBW harshly criticized. ${ }^{115}$

Chavis's enthusiasm for the genre was not shared by the rest of the national NAACP. There was dispute within the organization with many of the policies Chavis was pursuing, especially his support of gangsta rap. A few days after Chavis's rap forum, for instance, the organization released a public statement condemning gangsta rap for its promotion of violence. $^{116}$

The NAACP's Maryland chapter also seemed convinced that gangsta rap encouraged antisocial behavior among blacks. The chapter's executive officers did a study that assessed the growth of black dependency and crime in the state. While the organization believed that limiting welfare could curb dependency, it also concluded that one of the best ways to suppress crime was to limit the influence of gangsta rap. To this end, it also proposed a hearing to assess the genre's impact on black listeners. ${ }^{117}$

Critics also used public rallies as forums for denouncing the genre. One article in the New York Amsterdam News describes how William Tucker, C. Delores Tucker's husband, organized a NPCBW rally outside of the Apollo Theater to protest Time Warner's merger with EMI Music Group, a company that distributed gangsta rap records. Group demonstrations were a common tactic that Tucker and her supporters employed to protest companies that distributed gangsta rap. They had been arrested throughout the 1990s for holding demonstrations outside of

\footnotetext{
${ }^{115}$ James Bock, “Thinking Young, NAACP Embraces Rap,” Baltimore Sun, February 10, 1994, accessed May 20, 2020, https://www. baltimoresun.com/news/bs-xpm-1994-02-10-1994041108-story.html.

116“"The NAACP in Opposition of Gangsta Rappin," Crisis (00111422)(EBSCOhost) 101, no. 3 (1994): 1, accessed May 20, 2020, http://libproxy.lib.ilstu.edu/login?url=https://search.ebscohost.com/login.aspx? direct=true\&db=f5h\& $\mathrm{AN}=9408160637 \&$ site $=$ eds-live \&scope $=$ site.

${ }^{117}$ Charles Babington, "Md NAACP Goes After 'Gangsta'; Resolutions Include Plea for Legislative Hearings on Violent Music," Washington Post (Nexis Uni), February 15, 1994, accessed May 20, 2020, https://advance-lexiscom.libproxy.lib.ilstu.edu/api/document?collection=news\&id=urn:contentItem:3S7T-7CK0-0088-P1GX-00000$00 \&$ context $=1516831$.
} 
Tower Records retail stores in Pennsylvania. ${ }^{118}$ During this demonstration, William echoed familiar arguments about gangsta rap and its connection to black crime. Arguing that the genre “"glorifies anti-social behavior in African-American men," he noted that black male incarceration began to skyrocket in 1992 and 1993 when gangsta rap was becoming popular. ${ }^{119}$

While it was not uncommon for censors to make connections between gangsta rap, crime, and violence, some went to greater lengths than others. Such was the case with Nathan McCall. McCall was a writer for the Washington Post. In 1993, he published an article that looked at the genre's influence on black youth. In many ways, it reads less like an op-ed and more like a pseudo-sociological study of the genre's effects on black behavior.

First, he argued that black violence and crime were consequences of gangsta rap and negative social influences. He contended that while the genre was relatively "harmless" to most listeners, it could have a negative impact on "at risk" black youth, whom he suggests tended to be more receptive to gangsta rap due to "complex social factors," like "public apathy, parental neglect, [and] the allure of drugs and guns." 120

He also blamed the supposed surge of violence in black rural areas on the genre. He explained that the growing accessibility of gangsta rap in these areas coincided with the "unexplained change in the values and behavior" of their populations, which had been "cut off geographically from violent urban influences."121

Lastly, he drew on statistics to make a case for gangsta rap's supposed deleterious effects

\footnotetext{
${ }^{118}$ Conway, "Gangsta's Paradise," 18-19.

${ }^{119}$ Zamgba J, Browne, "Political Congress of Black Women protests Time Warner/EMI merger: say gangsta rap destroys community," New York Amsterdam News(EBSCOhost), May 25, 2000, 3, accessed May 20, 2020, https://

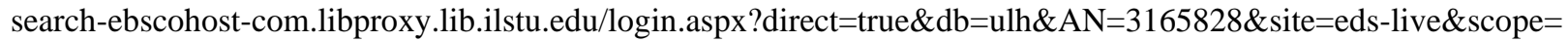
site.

${ }^{120}$ Nathan McCall, "My Rap Against Rap," Washington Post (Nexis Uni), November 14, 1993, accessed May 20, 2020, https://advance-lexis-com. libproxy.lib.ilstu.edu/api/document?collection=news\&id=urn:contentItem:3S7T7W30-0088-P40H-00000-00 \&context $=1516831$.

${ }^{121}$ McCall, "My Rap."
} 
on black behavior. He asserted that in Washington alone, from 1988-1990, black juveniles who were arrested on homicide charges rose from $26 \%$ to $67 \%$. On a national level, he noted that black juvenile killings had almost doubled since 1984 and that violent crimes among them had risen by almost $40 \%$. He also noted how this increase in violence and criminality occurred when gangsta rap was growing in popularity. He concluded by suggesting that concerned individuals and groups pursue censorship to negate the genre's negative influence on black youth. ${ }^{122}$

These examples show that censors often paralleled each other in their criticisms of gangsta rap. They argued that the genre was responsible for increasing rates of black violence, criminality, and incarceration and often provided statistics to make their case. Yet their criticisms have distinct elements that speak to underclass ideology.

C. Delores Tucker's and Butt's proposals for inoculating blacks from gangsta rap's negative influence were based on a belief that violence and crime in black communities were driven by antisocial behavior. They argued that the best way to challenge these issues was by supporting preventative measures that were aimed at altering behavior. Yet this caused them to ignore how economic factors exacerbated such issues. John Clegg and Adaner Usmni, for instance, note that the increase in property and violent crimes among African Americans in central cities between 1960 and 1995 could be attributed to factors like deindustrialization, automation, and a lack of funding for social services. ${ }^{123}$ Notwithstanding such evidence, Tucker and Butts instead saw violence and crime as indicators of social pathology. Therefore, their criticisms of the genre can be linked to underclass ideology.

\footnotetext{
${ }^{122}$ McCall, "My Rap."

${ }^{123}$ John Clegg and Adaner Usmni, "The Economic Origins of Mass Incarceration," Catalyst 3, no. 3 (Fall 2019): 19, 23,26 .
} 
While Tucker and Butts put their faith in schools and churches to shape black behavior, censors like William Tucker, Law, and Barron took a different route. They each argued that gangsta rap was responsible for increasing rates of violence and criminal activity among black males while Law specifically expressed a belief that fostering conformity among them should accompany any efforts to censor the genre. This suggests that they believed that black crime and violence were largely the fault of black males who exhibited pathological behavior, which, like Tucker's and Butts's criticisms, cannot be divorced from underclass discourse.

Underclass ideology also informed McCall's insights on gangsta rap and its influence on African Americans. Underlying his arguments was an assumption that blacks who came from dysfunctional and urban communities were prone to violent, criminal behavior, which is a central tenet of underclass ideology.

\section{Sexual Promiscuity}

Aside from crime and violence, censors were also concerned with the excessive misogynistic themes in gangsta rap. While they expressed their disapproval of lyrics from black male rappers that cast black women's sexual behavior in a negative light, they also directed their criticisms toward black female rappers who supposedly projected black female sexual stereotypes. For example, Bytches With Problems, a female rap duo that was often compared to 2 Live Crew, were known for songs like "Is the Pussy Still Good?" and "Two Minute Brother," which glorified sexually-promiscuous behavior among women. ${ }^{124}$ Troubled by such lyrics and the messages they conveyed, David Christian of the Tampa Bay Male Club, a program where professional black men mentored inner-city black boys, commented that "'these young women are not presenting themselves as very ladylike when they go on stage singing, 'Shake baby

\footnotetext{
${ }^{124}$ Bytches With Problems, The Bytches, MP3 audio, Def Jam Columbia, 1991.
} 
shake, shake baby boom." $" 125$

Censors were also concerned that young black girls internalized these sexual messages, which seemed to affect their view of themselves and their behavior. In 1995, for instance, a reporter interviewed five black girls about gangsta rap. Not only did they express that they saw nothing wrong with rappers referring to them as bitches, but they also revealed that "they don't hesitate to shake their rumps" when listening to certain songs. ${ }^{126}$

Censors also argued that gangsta rap was problematic because it produced stereotypes about black women that were antithetical to what they believed to be genuine roles for black women. The Black Leadership Forum (BLF), which is a consortium of black civil rights organizations founded in the 1970s, opined that the genre corrupted the image of black women, whom it believed should be seen as mothers and nurturers: "Misogynistic rap and videos... present a destructive, unhealthy, and unacceptable model of black male and female interaction. An entertainment industry which grows wealthy through verbal and visual assaults on African American mothers, daughters, and sisters - the primary transmitters of our culture and the principal guarantors of our future generations - can only be viewed as a participant of black genocide." 127

To counter such imagery and its corollary effects on black female sexual behavior, Chloe Coney, who was the director of the Lee Davis Neighborhood Development Corporation in Tampa, Florida, went about enacting measures that would affect black girls' morale. She often

\footnotetext{
${ }^{125}$ Tracie Reddick, "The rap on gangsta rap; Critics call for a boycott of rap that puts down women. Others say it's only a symptom of deeper problems," The Tampa Tribune (Florida) (Nexis Uni), August 7, 1995, accessed June 10, 2020, https://advance-lexis-com.libproxy.lib.ilstu.edu/api/document?collection=news\&id=urn:contentItem:3SD5-X 1T0-0094-00BG-00000-00\&context=1516831.

${ }^{126}$ Tracie Reddick, "'Not all gangsta rap is bad'; Young fans say they relate to hard-edged rap, even if it degrades women," The Tampa Tribune (Florida) (Nexis Uni), August 7, 1995, accessed June 10, 2020, https://advance-lexiscom.libproxy.lib.ilstu.edu/api/document?collection=news\&id=urn:contentItem:3SD5-X1T0-0094-00BF-00000-00\& context $=1516831$.

127 Joint Center, "Political Trend Letter," 2.
} 
complained how "inner-city girls raised in fatherless homes" often accepted adverse treatment from African-American boys in their neighborhood, like being called derogatory names.

Opposing what she saw as a focus on African-American males and the issues they faced, Coney sought to develop a program where professional black woman would "help at-risk girls blossom into self-confident adults." She argued that such a strategy was necessary because black girls' "self-esteem levels have dropped down to zero. If we teach our girls to value themselves, then maybe they won't look to rappers, and other men, to gauge their self-worth."128

Through their criticisms of and efforts to negate gangsta rap's negative influence on black female behavior, censors often reinforced conservative sensibilities about black women. Failing to consider black women's issues in the context of racial and gender inequality, they instead stressed the importance for them to adopt conservative behavior and gender roles; that is, to be chaste, mothers, and nurturers. Therefore, it can be argued that black liberal censorship in regard to sexual promiscuity was grounded in criticisms of black female sexual behavior that were popular in underclass and welfare discourse.

\section{Family Disorganization}

Much like their ideas on crime, violence, and sexual promiscuity, censors believed that gangsta rap had a negative impact on black families. They often argued that the genre undermined family values. Such a critique seems to have partly motivated Tucker's censorship efforts. When she contacted Carol Moseley-Braun about organizing a congressional hearing on gangsta rap's impact on listeners, for instance, she stated in a letter to her that black children were being "'bombarded with so many negative messages that undermine positive family values [and] our authority as parents.", 129

\footnotetext{
${ }^{128}$ Reddick, "The rap on gangsta rap."

${ }^{129}$ Quoted in Conway, "Gangsta's Paradise," 26.
} 
Tucker took her critiques a step further at the 1994 anti-crime conference. Drawing on history, Tucker suggested that the misogyny displayed in gangsta rap did more to cause the moral erosion of the black family than any of its past struggles:

For 400 years, profit came before principle, as black women bore the brunt of slave masters' degradation. But even through the Middle Passage, the peculiar institution of slavery, the spirit of black women and their families could not be broken. Today, however, through the lyrics of rappers, who display no respect for women, no respect for families, and little respect for themselves, the souls of our sisters are being destroyed and so to their progeny. ${ }^{130}$

While Tucker languished over gangsta rap's role in the moral decline of the black family, critics like Butts were more concerned with how it supposedly encouraged black teenage pregnancy. In a CBS interview, for instance, Butts complained how he often saw young girls in central Harlem, a predominantly black community, imitating the sexual behavior displayed in rap videos. He argued that there was a direct relationship between such behavior and out-of-wedlock births among black teenage girls. ${ }^{131}$

This concern about the relationship between teenage pregnancy and gangsta rap also informed measures that the Minneapolis Urban League took to deal with the issue in Minnesota. In 1980, black teenagers in the state were three times more likely to get pregnant than their white peers, yet it had increased to five times by 1999. The state also ranked in the top five for states with high rates of black teenage pregnancy, despite having one of the lowest overall and white teen pregnancy rates in the nation. ${ }^{132}$

\footnotetext{
${ }^{130}$ Tucker, "Violence Against Women," 28:43-29:14.

131"Reverend Calvin Butts Discusses Rap Lyrics He Finds Sexually and Racially Offensive," CBS News Transcripts (Nexis Uni), May 12, 1993, accessed May 20, 2020, https://advance-lexis-com.libproxy.lib.ilstu.edu/api/document? collection=news\&id=urn:content Item:3SJK-KY10-009C-B036-00000-00\&context=1516831.

${ }^{132}$ Maja Beckstrom, "Racial 'Pregnancy Gap' Spurs Search for Answers; Rate for Minnesota's Black Teens Five Times Higher Than for Whites," Saint Paul Pioneer Press (Nexis Uni), September 19, 1999, accessed May 20, 2020, https://advance-lexis-com.libproxy.lib.ilstu.edu/api/document?collection=news\&id=urn:contentItem:472CNS20-01K4-G10G-00000-00\&context=1516831.
} 
Many critics argued that poverty could help explain the gap. They suggested that black adolescents in the state became pregnant sooner because they tended to come from low-income neighborhoods with limited prospects for the future: "If teens live in poor neighborhoods surrounded by crime, drugs, unemployment and poor schools, what future can they imagine for themselves?" asked Yusef Mgeni, president of the Urban Coalition, an advocacy and research group for issues affecting low-income people in the Twin Cities. ${ }^{133}$

While many conceded that poverty was a central cause of rising black teenage pregnancy rates, others paradoxically sought out behavioral solutions to the issue. Minnesota's Health Department, for instance, founded the African-American Teen Pregnancy Prevention Project, which was tasked with seeking out preventative, "culturally specific programs" for AfricanAmerican teenage girls. One such program was the Heavy, Intense Prevention Program for Homies, Oakies, Players and Perpetrators (which ironically spelled out the acronym "HIPP HOPP"). Directed by Lolita Davis Carter, a program supervisor at the Minneapolis Urban League, it was run through five junior high schools and high schools in the city. In addition to having a panel of teen moms and lectures on family planning, it also had a week-long class on teaching girls how gangsta rap demeaned African-American women. "At the beginning of the class, they're like, 'Gangsta rap is down...it's good she's wearing a g-string because we want to see her shake her bootie, But by the end of the class, it's different. They're saying, 'Maybe some of the gangsta rap is not respectful to African-American women," Carter said of the class's effect on students. ${ }^{134}$

Teenage pregnancy was not the only family-related issue that censors believed was caused by gangsta rap. They also believed that the genre played a role in depriving black families

\footnotetext{
${ }^{133}$ Beckstrom, "Racial 'Pregnancy Gap."”

${ }^{134}$ Beckstrom, "Racial 'Pregnancy Gap."”
} 
of good fathers. As mentioned before, censors believed that the genre encouraged criminal behavior among African-American males. This in turn, they believed, had a direct effect on their abilities to be fathers. In a speech given at a NPCBW awards brunch, for instance, Tucker explained that the organization had a "covenant" to keep with society to "sustain [the] respect and dignity of [black] men." She believed that its mission was being compromised by "elements [that] conspired to denigrate [black] men thereby causing the breakup of families." She believed that black men were unable to carry out their responsibilities as fathers because they were afflicted by the “"3P Plague'-probation, prison, [and] parole."135

While Tucker does not specify what "elements" left black homes without good fathers, her commentary elsewhere suggests that she saw gangsta rap as a central cause. She expressed her concerns at a Time Warner stockholder meeting in 1996. After her successful attempt to get Time Warner to sell Interscope, she bought stocks in the company and became a regular fixture at stockholder meetings. She often used these meetings as opportunities to protest the company's continued investment in the genre. ${ }^{136}$ At the 1996 meeting, she complained about the genre's role in depriving black families of good fathers. After berating Warner's C.E.O. Gerald Levin for promoting music that was thought to encourage black male criminality, she suggested that this in turn led black fathers to either be absent from the home or unfit to raise their children: "I told him about the black males-25 percent are either in jail or under some form of judicial regulation. I said...'how are we going to raise a race of people with no men?"”137

Critics also believed that gangsta rap affected black males' ability to be fathers by

\footnotetext{
${ }^{135}$ C. Delores Tucker, "Remarks at the National Political Congress of Black Women's 16th Annual Awards Brunch," Vital Issues: The Journal of African American Speeches 10, no. 4 (Winter 2000): 21.

${ }^{136}$ Conway, "Gangsta's Paradise," 24-25.

${ }^{137}$ Sonya Ross, "A Lonely Crusader Against Gangsta Rap," Chicago Tribune (ProQuest), September 15, 1995, accessed May 20, 2020, https://search-proquest-com.libproxy.lib.ilstu.edu/chicagotribune/docview/2074649969/ fulltextPDF /DFA3955009F54CDAPQ/1? accountid=11578.
} 
providing them with a false sense of manhood. Leonard Pitts, a newspaper columnist, explored this in an article written for the San Jose Mercury News. He explained that in response to coming from fatherless homes, many young black males internalized the antisocial themes prevalent in the genre, causing them to adopt a callous demeanor. He further complained that their desire to present themselves in this manner left little room for them to learn what it meant to be responsible fathers. ${ }^{138}$

Aside from looking at the genre's effect on black teenaged girls and males, censors also argued that the genre corrupted black children. Tucker believed that children who did not come from strong, two-parent families were more susceptible to its antisocial influences. In one speech, for instance, she decried how black children influenced by the genre, who had no understanding of the "traditional family," were much like a young black man she met when she was still Secretary of State, who "either had no home at all or come from a dysfunctional home where the parents suffer from debilitating social or mental ailments." 139

Tucker reiterated her concerns at a news conference with Bennett and Senator Joseph Lieberman. Lieberman joined Tucker and Bennett's anti-rap crusade in 1996, when they called for Warner, BMG, PolyGram, Thorn-EMI, and Sony Music to drop gangsta rappers from their labels. ${ }^{140}$ Tucker used the conference as a platform to discuss the genre's debilitating effects on black children. Citing gangsta rap albums like Dogg Food, she opined that the genre had a negative influence on children who came from fatherless households and whose mothers were teenagers and on drugs. She also complained that her six-year-old grand-niece, who frequently

\footnotetext{
${ }^{138}$ Leonard Pitts, Jr., "COLD, HARD, BAD, SAD DUDES," San Jose Mercury News (Nexis Uni), December 7 , 1994, 7B, accessed May 20, 2020, https://advance-lexis-com.libproxy.lib.ilstu.edu/api/document?collection=news\& id=urn: contentItem:472S-WSW0-01 K4-D3BX-00000-00\&context=1516831.

${ }^{139}$ Tucker, "Remarks at George H. Gallup," 15.

${ }^{140}$ Conway, "Gangsta's Paradise," 24.
} 
listened to the music, had become a "social leper" whom parents did not around their "decent children."141

Like many who were swayed by the conservative political culture of the era, censors rarely looked at black teenage pregnancy from a socioeconomic viewpoint. As public health expert Arline Geronimus reasons, early pregnancy can be a rational choice for adolescents who come from poor, urban families. She argues that because black adolescents in these families tend to have shorter life expectancies and limited educational and employment opportunities, many might decide to have children young, since it would make it more likely that they would be able to raise them into adulthood with the support of an extended kin network. Censors, however, ignored how such factors might affect black adolescents' childbearing options and instead viewed teenage pregnancy as "one in a constellation of pathological behaviors particularly engaged in by an urban, African American 'underclass."”142

Censors also thought about black fathers in terms of behavior. Their ideas preceded from the view that fathers were meant to be both leaders and financial providers in their families, and their failure to do so was indicative of family breakdown. Yet censors failed to consider how fathers' inability to carry out these roles could be a result of socioeconomic factors. Geronimus notes that in poor black urban families, a child's biological father is often absent or unable to be the sole breadwinner because they, like black adolescent girls, tend to have short life expectancies and low-wage jobs. In such instances, male relatives often "supplement or even substitute for parental support." ${ }^{143}$ Censors' willingness to instead link black males'

\footnotetext{
${ }^{141}$ C. Delores Tucker, Sen. William Bennett, Sen. Joseph Lieberman, and Sen. Christian Pinkston, "WWW-HOLDS NEWS CONFERENCE WITH OTHERS TO DISCUSS OBSCENE MUSIC," FDCH Political Transcripts (Nexis Uni), May 30, 1996, accessed May 20, 2020, https://advance-lexis-com.libproxy.lib.ilstu.edu/api/document? collection=news\&id= urn:contentItem:3SJF-BN90-009G-547Y-00000-00\&context=1516831.

${ }^{142}$ Arline T. Geronimus, "Teenage Childbearing and Personal Responsibility: An Alternative View," Political Science Quarterly 112, no. 3 (Autumn 1997): 424.

${ }^{143}$ Geronimus, "Teenage Childbearing," 426.
} 
unpreparedness for fatherhood solely to pathology suggests that they were more so influenced by underclass ideology than the culture wars or a generational conflict.

Censors' arguments about black children also reflect an influence of underclass ideology. They suggested that children who did not come from healthy, two-parent families were more likely to engage in antisocial behavior. Yet this view assumes that such families are the only ones that can effectively rear children. As alluded to before, extended kin networks often help to raise children in poor urban black families.

\section{Conclusion}

At first glance, blaming major issues like crime, violence, sexual promiscuity, and family disorganization on a musical genre seems absurd. Yet when considering the political context of the era, one can begin to make sense of censors' criticisms and their efforts to censor gangsta rap. In a political culture that had begun to retreat from its commitment to poor minorities and instead blame them for their own problems, censors began to reevaluate how they thought about and dealt with black social issues. They often identified pathological behavior as a cause of such issues. Given this, it seems reasonable that blacks would target gangsta rap, since it was a genre that was immensely popular among African Americans and, as previously shown, contained antisocial messages that some of its black listeners were receptive to.

The measures that censors took to subdue the negative influence of gangsta rap was predicated on a belief that bad behavior was a major impetus for black crime and violence. While it is true that crime and violence were becoming growing issues in black urban areas, censors often misdiagnosed their cause. As blacks in these areas were faced with increasing joblessness and poverty due to the shift from an industrial to an information technology economy, they were left with few options for gainful employment. Therefore, their turn to crime, and the violence 
that accompanied it, were more so consequences of economic changes. Censors, however, pursued measures that were meant to target behavior rather than address these changes, which reflects the influence of underclass ideology on their thinking about the genre.

Censors also faulted gangsta rap for its sexualized depiction of black women because they believed that such imagery encouraged black girls to engage in inappropriate sexual behavior. The solution, therefore, was to build black girls' self-respect and emphasize their roles as mothers and nurturers. Such themes were common in policy debates about welfare reform and the black underclass in the 1980s and 90s, where many were committed to suppressing sexual immorality among poor black women and enforcing their role as mothers in nuclear, two-parent families. In this sense, censors' views on black female sexual promiscuity and gangsta rap can be seen in the context of underclass ideology and neoliberalism.

Censors also sidestepped the broader economic implications of issues affecting black families. Because of their socioeconomic status, poor, urban blacks often have approaches to family life that are uncommon in nuclear families, such as embracing teenage pregnancy, male kin taking on roles traditionally reserved for fathers, and extended kin networks taking an active role in nurturing children. Rather than seeing these as rational approaches to family life given their socioeconomic backgrounds, censors instead saw teenage pregnancy, fathers' inability to lead their families, and the failure of two-parent families to rear children as evidence of pathology, which is also in line with underclass ideology. 
CHAPTER III: THE NATION OF ISLAM'S RESPONSES TO GANGSTA RAP, 1995-2000

On October 16, 1995, Rev. Jesse Jackson gave a speech at the Million Man March. The March, which was an event sponsored by the Nation of Islam (NOI) that urged black men to take responsibility for issues like crime, poverty, and family disorganization, seemed to be an ideal venue for Jackson. Since the early 1990s, personal responsibility and mentorship had been central themes of his anti-crime and anti-violence initiatives, and the March provided him with an opportunity to reiterate those themes. While his speech called on the federal government to address economic inequality among poor urban blacks, it also challenged black men to "stop [their] self-destructive behavior" and become better fathers and role models to at-risk black children. $^{144}$

A few decades prior to this, Jackson speaking at an event sponsored by the NOI would have seemed unlikely, given the organization's tenuous relationship with black liberals. Since the 1960s, the Nation, a black separatist organization, had constantly been at odds with black liberals, who had sought out black progress through integration. By the mid-1990s, however, both were committed to the belief that pathological behavior was a major impetus for black inequality.

This new consensus in black politics was evident with the Nation's involvement in the gangsta rap censorship movement. The Nation, like black liberals, believed that gangsta rap was one of the major causes of black pathology, and therefore directed its efforts towards censoring it. More so than its liberal counterparts, however, the Nation believed that the genre could be used to counter the social pathology that it believed characterized black life.

This chapter explores the NOI's involvement in the censorship movement. First, it looks

\footnotetext{
${ }^{144}$ Jesse L. Jackson, "Remarks," in Million Man March/Day of Absence, 34-35.
} 
at the scholarship on the NOI's ideas about black social pathology, and demonstrates how it is insufficient in helping us understand the organization's censorship efforts in the context of black politics in the 1990s and early 2000s. It then transitions into a discussion on the Million Man March. It looks at the March's central ideas, their connection to black men, and how both the Nation and black liberals used them to justify censorship.

It then delves into the Nation's censorship efforts amid the East Coast/West Coast feud. The Nation believed that the feud, which was a conflict between mainly East and West Coast rappers that ended after the shooting deaths of two prominent rap stars, contributed to a rise of " crime and violence among their black listeners. Consequently, Nation members sought to counter the genre's supposed negative influence through a variety of means, including peace rallies and summits.

The chapter also looks at how censors correlated their understanding of black women's sexuality with the rap music they believed these women listened to. While it considers the NOI's arguments about how the genre encouraged sexual promiscuity among black women, it also looks at similar arguments made during the Million Woman's March, an event that was inspired by the Million Man March and grounded in conservative ideas about women's roles.

It then looks at the NOI's censorship efforts in relation to rap and the black family. It mainly looks at Farrakhan's and C. Delores Tucker's remarks on the subject in the context of the Million Family March, an event geared toward promoting family stability.

Lastly, it analyzes the music of two gangsta rappers who were influenced by the Nation during this period: Ice-T and Ice Cube. Both rappers made connections between behavior and the social issues that blacks faced, and are therefore essential in understanding how gangsta rappers could make music that was in tandem with the goals of NOI censorship. 
The NOI and Black Pathology: A Literature Review

The scholarship on the NOI has attempted to make sense of the organization by exploring its many facets, including its relationship to broader black politics and nationalism, its ideas on gender roles, and its beliefs about black economic development. Scholars who have analyzed these themes, such as Robin D.G. Kelley, Sundiata Keita Cha-Jua, Clarence Lang, Dean Robinson, and Nikol G. Alexander-Floyd, have also looked at the organization's thought on black pathology. By assessing their scholarship in this area, we can begin to see where it falls short on helping us understand how the NOI fits into the milieu of black politics in the 1990s and early 2000s.

Kelley briefly touches on the NOI's ideology in his book Yo Mama DisFUNKtional! He locates the organization's ideas about black social pathology in black self-help philosophy. Rooted in the ideas of figures like Booker T. Washington and Marcus Garvey, this ideology entails that blacks should work to find solutions to issues that afflict their communities. Its adherents often embrace the view that these issues stem from blacks' moral flaws. He notes, for instance, that the NOI's People Organized and Working for Economic Rebirth (POWER) sought to deter blacks from committing crimes and doing drugs in addition to addressing unemployment. $^{145}$

Much like Kelley, Cha-Jua and Lang look at the NOI's ideas about black pathology in a narrow racial context. They argue that such ideas are rooted in the organization's embrace of militant black conservatism. Drawing on themes associated with monotheistic religions, this ideology holds that African Americans exhibit pathological behavior and are therefore in need of moral guidance from black elites. They also argue that this conservatism was clearly at play

\footnotetext{
${ }^{145}$ Robin D.G. Kelley. Yo Mama's Disfunktional!: Fighting the Culture Wars in Urban America (Boston: Beacon Press, 1997), 85, 87-88.
} 
during the Million Man March, since some of the major themes of the March were that blacks were morally "sick" and in need of "atonement."146

Unlike Kelley, Cha-Jua and Lang, who tend to look at the Nation's ideas in a vacuum, Robinson connects the organization's thought to broader American politics. In his book Black Nationalism in American Politics and Thought, for instance, Robinson argues that Farrakhan's views on blacks "position him at the far-right end of the political spectrum" with white conservatives and the religious right. ${ }^{147} \mathrm{He}$ further suggests that Farrakhan's alignment with the far right has informed measures that the NOI has taken to redress black pathology from the 1980s going forward. Like Kelley, he looks at POWER, and notes how Farrakhan believed that such an initiative would "“rebuild a stable black family life [and] drastically reduce the involvement of black people in crime and drugs." $" 148$

More so than any of the previous-mentioned scholars, Alexander-Floyd ties the Nation's ideas to underclass ideology. In an article that explores gender and black nationalism, AlexanderFloyd asserts that the patriarchal message central to the Million Man March grew out of a "black cultural pathology paradigm." She argues that the paradigm, or "narrative," posits that the many social problems that African Americans face stem from female-headed households. Therefore, any attempts to resolve these issues must include measures to promote patriarchal black families. She ties the narrative to different episodes that shaped the development of underclass ideology, like the publication of Moynihan's Negro Family and Raegan's speeches on the "welfare queen."149

\footnotetext{
${ }^{146}$ Clarence Lang and Sundiata Keita Cha-Jua, "Providence, Patriarchy, Pathology: Louis Farrakhan's Rise \& Decline," New Politics 6, no. 2 (Winter 1997), https://archive.newpol.org/issue22/chajua22.htm

${ }^{147}$ Dean Robinson, Black Nationalism in American Politics and Thought (New York: Cambridge University Press, 2001), 126-127.

${ }^{148}$ Robinson, Black Nationalism, 121.

${ }^{149}$ Nikol G. Alexander-Floyd, '”We Shall Have Our Manhood:' Black Macho, Black Nationalism, and the Million Man March,” Meridians 3, no. 2 (2003): 185-188.
} 
While each of these authors greatly contribute to our understanding of the Nation's ideology, their analyses is somewhat limited. They fail to consider, for instance, how the Nation's censorship efforts can be used to understand the growing consensus on inequality in black politics in the 1990s and 2000s. Coupled with black liberal censorship efforts, the Nation's efforts revealed a tendency in black politics to measure black inequality in terms of individual behavior rather than lack of opportunity. Therefore, looking at the Nation in this context illustrates the growing influence of neoliberalism on black politics during this period. It also captures the overall complexity of black politics, since it shows blacks' conservatism despite their political orientation.

\section{Million Man March and Gangsta Rap}

Spurred by a myriad of issues, including unemployment, crime, family dissolution, and blacks' portrayal in the media, Farrakhan made a call for the Million Man March in 1995. As evidence of the broad support that the Nation had garnered from African Americans by the 1990s, several African Americans of varying political orientations were involved in organizing the event. Benjamin Chavis, a liberal Democrat, served as the March's national director. ${ }^{150}$ Chavis, who had been ousted from his position in the NAACP for a sexual harassment scandal, would later convert to Islam and serve as the Nation's East Coast Regional Minister. ${ }^{151}$ Maulana Karenga, a black nationalist, was another key player, serving on the March's executive council. ${ }^{152}$

The March called for black men to practice "atonement, reconciliation, and

\footnotetext{
${ }^{150}$ Karenga, "Day of Absence Mission Statement," 141.

151“"WHAT EVER HAPPENED TO . . B BENJAMIN F. CHAVIS JR.,"Washington Post, April 14, 2006, A15, accessed June 7, 2020, https://advance-lexis-com.libproxy.lib.ilstu.edu/api/document? collection=news\&id=urn: contentItem:4JPX-HF30-TW87-N33C-00000-00\&context=1516831.

${ }^{152}$ Karenga, "Day of Absence Mission Statement," 141.
} 
responsibility" in their daily lives. It stressed that black men should atone for their supposed moral deficiencies and strive to be "self-corrective" in their behavior. ${ }^{153}$ It also suggested that they reconcile their differences with others as a means of creating unity and solving issues in their communities. Finally, it called for "each Black man...to renew and expand [their] commitment to responsibility in personal conduct, in family relations and in obligations to the community."154

The last theme struck a chord with the organizers of the March. They believed that many of the social issues that African Americans faced stemmed from black men's failure to be effective leaders and fathers. They therefore felt it was imperative to remind black men of their responsibilities:

Some of the most acute problems facing the Black community within are those posed by Black males who have not stood up; that the caring and responsible father in the home; the responsible and future-focused male youth; security in and of the community; the quality of male/female relations, and the family's capacity to avoid poverty and push the lives of its members forward all depend on the Black men's standing up. ${ }^{155}$

This message was not lost on black liberals. They believed that the lessons of the March could serve to inoculate blacks from gangsta rap's negative influences. Tucker, for instance, stated that she supported the March's goals to foster responsible black fathers and leaders. She hoped that such a move would counter attempts by the mass media to portray black men as antisocial and be "turned into a hurricane force to rid our communities of denigrating music" like gangsta rap. ${ }^{156}$ At a news conference attended by Tucker, Morris Shearin, a representative of a Washington NAACP locale, also hoped that the fervor created by the March would cause rappers

\footnotetext{
${ }^{153}$ Karenga, "Day of Absence Mission Statement," 142.

${ }^{154}$ Karenga, "Day of Absence Mission Statement," 144

${ }^{155}$ Karenga, "Day of Absence Mission Statement," 142.

${ }^{156}$ C. Delores Tucker, "Publisher's Statement," Vital Issues: The Journal of African American Speeches 6, no. 2 (1996): ii.
} 
to be more responsible about the content they produced: "These rappers are serving the same role as Judas--to sell out what is decent in our community...[i]n the spirit of the Million Man March and as men, it is time to tell these boys that it's time to stand up."157

While Farrakhan also chastised gangsta rap for its content, he also believed that the genre had redeeming qualities. Arguing that the genre contributed to the spread of "degenerate culture" in American society, Farrakhan instead implored rappers to use their music to spread positive messages in black communities. In building off this theme, he had Marchers recite a pledge promising to only support black artists who worked toward this goal. ${ }^{158}$

From these examples, we can see that the Nation and black liberals believed that the message of the March could convince rappers to stop promoting antisocial messages in their music, since they believed that such messages fueled black pathology. While this belief motivated much of the former's censorship efforts, it seemed to be the most pronounced in its anti-violence and anti-crime measures, which were aimed at curtailing black male-on-male violence and crime.

\section{Crime/Violence}

Farrakhan was not the only Nation member who commented on gangsta rap and its effects on listeners. Another was Conrad Muhammad. Born Conrad Tillard, Muhammad had been connected to the Nation as early as 1985, when he helped organize Farrakhan's Madison Square Garden appearance that year. After serving as the Nation's national student minister, Muhammad was appointed as leader of Muslim Mosque no.7. in Harlem in 1991. During his tenure as leader, he became known for mediating feuds between rappers, which earned him the

\footnotetext{
${ }^{157}$ Esther Iverem , "She's Out to Can 'Dog Food'; Activist Tucker Expands Assault on Gangsta Rap," Washington Post (Nexis Uni), December 15, 1995, F04, accessed June 4, 2020, https://advance-lexis-com.libproxy.lib.ilstu.edu/ api/document?collection=news\&id=urn:contentItem:3S7R-2YK0-0088-P1JJ-00000-00\&context=1516831. ${ }^{158}$ Louis Farrakhan, "Day of Atonement," in Million Man March/Day of Absence, 23,27.
} 
moniker "hip-hop minister." ${ }^{159}$ He played an important role in trying to resolve the East Coast/West Coast hip-hop rivalry.

The East Coast/West Coast rivalry was a feud mainly between New York and LosAngeles rappers. While the rivalry dates back to 1991, Bryan McCann argues that it started to intensify in 1994 after Tupac was robbed and shot in the lobby of Quad Studios in New York while Bad Boy CEO Sean "Puffy" Combs and his artist Biggie Smalls were there recording music. Believing Puffy and Smalls to be involved in the incident, Tupac proceeded to insult Smalls, the Bad Boy roster, and New York rappers in several diss tracks while other LosAngeles rappers made their own diss tracks aimed at New York rappers. This in turn caused New York rappers to respond with their own diss tracks. The rivalry began to settle down when both Shakur and Smalls were killed as a result of drive-by shootings in 1996 and 1997, respectively. ${ }^{160}$

Believing Shakur's death to be the result of violence in the hip-hop community, Muhammad organized a memorial service to commemorate the slain rapper's life and to reconcile the differences between feuding East and West Coast rappers. ${ }^{161}$ Billed as the "HipHop Day of Atonement" by the Muslim leader, one source estimates that as many as 2,000 people showed up for the event. ${ }^{162}$ While the event was meant to celebrate Shakur's life, Muhammad also saw it as an opportunity for attendees to "atone for the self-destructive, genocidal lifestyle" that claimed his life. With such a focus on the harmful effects of gangsta rap

\footnotetext{
${ }^{159}$ Peter Noel, "Escape from the Nation of Islam,” Village Voice, September 1, 1998, accessed June 18, 2020, https:/www.villagevoice.com/1998/09/01/escape-from-the-nation-of-islam/.

${ }^{160}$ McCann, Mark of Criminality, 99-100, 107, 109, 151.

${ }^{161}$ Esther Iverem, "Verses of Sorrow for Shakur; Rapper's Life Praised, Rebuked at Memorial," Washington Post (Nexis Uni), September 23, 1996, D01, accessed June 5, 2020, https://advance-lexis-com.libproxy.lib.ilstu.edu/api/ document?collection=news\&id=urn:contentItem:3S7T-9MH0-009B-N1B4-00000-00\&context=1516831.

162“Tupac Shakur memorial service draws mourners to New York mosque," Agence France Press (Nexis Uni), September 23, 1996, accessed June 5, 2020, https://advance-lexis-com.libproxy.lib.ilstu.edu/api/document? collection=news\&id=urn:contentItem:3TDD-V200-0031-V4YH-00000-00\&context=1516831.
} 
culture rather than Tupac himself, it comes of little surprise that one journalist described the event as "less a memorial and more a lesson in the futility of "gangsta" values [and] street violence." $" 163$

While a public reconciliation between East and West Coast rappers failed to take place, rappers in attendance were nevertheless inspired by the event's anti-violence message. For instance, they signed a pledge swearing off using violent lyrics in their work. ${ }^{164}$ Rapper Q-Tip even criticized other male rappers for the violent and criminal themes in their music: "I think the problem comes from black men, especially," Q- Tip said. "We have to learn to be responsible, caring and conscious of the things we say." 165

Aside from encouraging rappers to change their lyrical content, Nation members also believed that Tupac's life could be used to teach his African-American fans the dangers of emulating gangsta rap lyrics. Arthur Muhammad, a radio personality who emceed the Day of Atonement, was one such member. During the event, he urged attendees to discard the idea of "keeping it real," a popular mantra in gangsta rap that he felt encouraged black listeners to engage in antisocial behavior: "If keeping it real means having a gun in your waistband, if keeping it real means debasing the black woman, if keeping it real means dropping out of high school, if keeping it real means using violence and drugs, then we ain't gonna keep it real, we gonna keep it right."166

Echoing Arthur's sentiments, Conrad also offered his thoughts about "keeping it real."

\footnotetext{
${ }^{163}$ Michel Marriott, “At a Ceremony for Shakur, Appeals for Peace," New York Times (Nexis Uni), September 23, 1996, 3, accessed June 5, 2020, https://advance-lexis-com.libproxy.lib.ilstu.edu/api/document?collection=news\&id =urn:contentItem:3S89-3M80-0005-G1P0-00000-00\&context=1516831.

${ }^{164}$ Iverem, "Verses of Sorrow."

${ }^{165}$ Tim Whitmire, "SPURRED BY SLAYING OF SHAKUR, RAPPERS GATHER TO PROMOTE PEACE," Philadelphia Inquirer (Nexis Uni), September 23, 1996, A03, accessed June 5, 2020, https://advance-lexis-com. libproxy.lib.ilstu.edu/api/document? collection=news\&id=urn:contentItem:473F-CH70-01K4-921D-00000-00\& context $=1516831$.

${ }^{166}$ Iverem, "Verses of Sorrow."
} 
He reasoned that black males often internalized this message because they took their cues on how to behave from gangsta rap rather than seeking out churches or schools for moral guidance. The absence of such guidance, Conrad further argued, increased the likelihood of black men being murdered by other black men. ${ }^{167}$

The Nation was not solely concerned with the lack of guidance among rappers' black male fanbase. Its members also felt it necessary to act as a moral compass for rappers, many of whom they felt were led astray by the music industry. Conrad had such a relationship with the rapper Shyne, a New York-based rapper who was signed to Puffy's Bad Boy label. In 1999, he was involved in a nightclub shooting that left three people wounded. At a news conference, Conrad lambasted record executives for failing to offer him and other young rappers proper guidance, without which, he argued, "leaves them prey to the pitfalls of the gangsta lifestyle."168 In April 1997, Farrakhan organized a summit in Chicago that sought to quell the disputes that grew out of the East Coast/West Coast feud. Many of the rappers involved in the feud attended, including Snoop Dogg, Ice Cube, and Common Sense. In a press conference following the summit, Farrakhan asserted that the attendees had pledged to end their disputes with one another. He also explained that they would produce an album and tour that would commemorate Tupac and Biggie and promote atonement, reconciliation, and responsibility in black communities. He believed that these measures were necessary in "guiding our communities towards constructive behavior."169

\footnotetext{
${ }^{167}$ Iverem, "Verses of Sorrow."

${ }^{168}$ Peter Noel, "Hip Hop War," The Village Voice, April 24, 2001, accessed June 18, 2020,https://www.villiagevoice .com/2001/04/24/hip-hop-war/.

${ }^{169}$ Louis Farrakhan, "The Honorable Minister Louis Farrakhan Hip Hop summit 1997 pt.1," Chicago, Il, filmed on April 3, 1997, YouTube video, 9:51, https://www.youtube.com/watch?v=fQJRPKyKpGw.
} 
Farrakhan also hoped to use open forums to address gangsta rap and its supposed negative effects on black behavior. Months after the meeting, for instance, Farrakhan offered to sponsor a "peace and atonement"” conference in Washington that would include panels featuring rappers, music executives, and Afeni Shakur, Tupac's mother. It would also center around a panel called "Rappers for the Advancement of African People," which would explore "how the music form itself has affected the lives of young people in causing violence and urban decay." ${ }^{170}$ While there is no evidence to suggest that the album, tour, and conference ever went past the proposal stage, they reflected the NOI's belief that gangsta rap could be a cause of, and remedy to, black social pathologies.

Around the time that Farrakhan was trying to settle the East/West Coast feud, Conrad was forging new ground as a hip-hop activist. After being ousted as leader of Mosque no. 7 , Muhammad founded an organization that was geared toward promoting political activism among the hip-hop generation. Called Conscious Hip-Hop Activism Necessary for Global Empowerment (CHHANGE), the organization sought to get young blacks involved in several politically-charged issues, from voter registration to police brutality. ${ }^{171}$

While the main goal of Muhammad's organization was to encourage political activism among young African Americans, he also hoped that it could serve as an outlet for them to direct their energies toward more constructive channels. He felt that they spent too much of their time emulating gangsta rap, which he argued accounted for the high rates of mass incarceration, violence, sexual exploitation, and drug crimes among them. He therefore felt that his

\footnotetext{
${ }^{170}$ Esther Iverem, "Farrakhan to Sponsor Anti-Violence Rap Concert in D.C.," Washington Post (Nexis Uni), August 10, 1997, B05, accessed June 6, 2020, https://advance-lexis-com.libproxy.lib.ilstu.edu/api/document?collection= news\&id=urn:contentItem:3S7T-7Y30-009B-N0DP-00000-00\&context=1516831.

${ }^{171}$ Risasi Z. Dais, “A New Day for 'CHHANGE," New York Amsterdam News (EBSCOhost), September 17, 1998, 3, accessed June 6, 2020, https://search-ebscohost-com.libproxy.lib.ilstu.edu/login.aspx?direct=true\&db=f5h\&AN= $1159368 \&$ site $=$ ehost-live $\&$ scope $=$ site .
} 
organization could "give Black youth an alternative to the thug lifestyles glamorized in hip-hop videos." 172

\section{Sexual Promiscuity}

Crime and violence were not the only issues that convinced the NOI to censor gangsta rap. Sexual promiscuity was also a target of its censorship efforts. In May 1997, for instance, Farrakhan convened a second hip-hop summit where he briefly touched on how the genre seemed to encourage young black girls to engage in sexually-promiscuous behavior. He argued that because rap made black girls think of themselves as "bitches and hoes," it made it easier for them to be prostitutes. ${ }^{173}$ This example shows that with its criticisms of rap, the NOI, like black liberals, normally viewed sexual behavior through a gendered lens, since black girls and women were singled out for their promiscuity more so than their black male counterparts.

Concerns over black women's behavior partially motivated the 1997 Million Woman March in Philadelphia. Inspired by the Million Man March, the event was organized by activists Phile Chionesu and Asia Coney and sought to address several issues facing black women, including their lack of professional development and homelessness. Aside from its more practical goals, they also felt that the March needed to emphasize black women's roles as nurturers, since they, as Coney put it, were "responsible for teaching morals and values of womanhood."'174

One person who spoke at the March was Sistah Souljah. Souljah was a Bronx rapper who was known for her inflammatory remarks about racial matters. In 1992, she attracted national attention for her remarks on the Los Angeles Riots. While commenting on the black-on-white

\footnotetext{
${ }^{172}$ Dais, "CHHANGE."

${ }^{173}$ Louis Farrakhan, “Chicago Hip Hop Summit (2),” MP3 Audio, May 13, 1997, 32:43-33:57.

${ }^{174}$ Asia Coney, "Remarks at the Million Woman March," Vital Issues: The Journal of African American Speeches 7 , no.4 (1997): 4-5.
} 
violence during the Riots, Souljah asked during an interview that "if black people kill black people every day, why not have a week and kill white people...[d]o you think that somebody thinks white people are better, or above dying?" Clinton condemned Souljah's comments at a Rainbow Coalition meeting to distance himself from the radical views that tended to be associated with his party, which became known as a Sistah Souljah moment. ${ }^{175}$

At the March, Souljah spoke on the supposed connection between rap and black women's sexual behavior. Condemning black women who practiced infidelity and appeared semi-nude in public, Souljah argued that they needed to concentrate on being respectable. She felt that their ability to do so was being jeopardized by female rappers like Lil' Kim and Foxy Brown, whom she suggested taught them to define themselves in terms of their sexuality. ${ }^{176}$

Family

In addition to crime, violence, and sexual promiscuity, the NOI also explored the connection between rap and the black family. At the April and May 1997 hip-hop summits, for instance, Farrakhan argued that rap had the potential to promote family stability. At the former, he urged rappers like Snoop Dogg to produce lyrics that would encourage black men to be better patriarchs in their families. ${ }^{177}$ At the May summit, he argued that rappers should discourage husbands from abusing their wives. ${ }^{178}$

Seeking to promote the development of stable black nuclear families, the NOI went about organizing the Million Family March. In July 2000, Farrakhan held a press conference where he discussed his reasons for the March, which would be held in November that same year. He

\footnotetext{
${ }^{175}$ Carter, Brother Bill, 10-13.

${ }^{176}$ Sister Souljah, "Remarks at the Million Woman March," Vital Issues: The Journal of African American Speeches 7, no.4 (1997): 7.

${ }^{177}$ Louis Farrakhan, “Chicago Hip Hop Summit,” MP3 audio, April 3, 1997, 1:43:24-1:43:40.

${ }^{178}$ Farrakhan, "Chicago Hip Hop Summit (2)," 1:40:00-1:40:12.
} 
argued that while such a march was needed as a response to the moral erosion of American families, he admitted that he was particularly concerned about the erosion of black families. Like Moynihan, Farrakhan suggested that weak family structures led to other forms of social pathologies among blacks, including female-headed households, involvement in gangs and crime, and drug use. Therefore, he stressed that federal policy should be geared toward strengthening the family. ${ }^{179}$

Farrakhan also suggested that music played a significant role in the decline of family values. He stated, for instance, that such values were being undermined by the "cultural degeneracy" that was being pushed on children through music. ${ }^{180}$ While he does not specify what kind of music he was referring to, his sentiments about rap music expressed during the Million Man March make it likely that he was referring to the genre.

One of the March's main supporters was Russell Simmons. A rap mogul, Simmons was responsible for rallying many of the rappers who attended and performed at the event. $\mathrm{He}$ believed that their participation in the March could help send a message that they supported the idea of building stronger families: "The rap community has always been one thing: real. They'll talk about how much money they're making... They'll brag about their sponsorship deal with Coca-Cola. So they also should also have guts enough to talk about family.""181

C. Delores Tucker was another figure who supported the March. In her speech at the event, she suggested that rap music weakened families' abilities to effectively rear and nurture children by exposing them to content that conveyed antisocial messages. She also reiterated the

\footnotetext{
${ }^{179}$ Louis Farrakhan, “Million Family March,” C-SPAN, July 14, 2000, 02:47-05:43, accessed June 18, 2020 , https://www.c-span.org/video/?158235-1/million-family-march.

${ }^{180}$ Farrakhan, "Million Family March," 05:43-06:25.

${ }^{181}$ David Segal, "Rappers Give Leg Up to Million Family March,” Washington Post (Nexis Uni), October 14, 2000, C01, accessed June 6, 2020, https://advance-lexis-com.libproxy.lib.ilstu.edu/api/document?collection=news\&id= urn:contentItem:41DP-8DP0-00RP-M00R-00000-00\&context=1516831.
} 
need for measures that would curb gangsta rap's negative influence on black youth, like constructing boarding schools that would be aimed at negating black youths' antisocial behavior. ${ }^{182}$ While Tucker had advanced similar arguments and proposals throughout the 1990s, her willingness to speak at a NOI-sponsored event centered around promoting family stability further reflects the consensus that black liberals and the NOI had on such an issue.

Black family development and its relationship to rap music was also a central theme at a 2001 hip-hop summit organized by Simmons and the NOI. During his keynote address, Farrakhan implored that rappers should use their lyrics to teach black youth to respect black women, since disrespecting them would have an adverse effect on how they nurtured and raised their sons. ${ }^{183}$

Analysis

These examples show that the NOI, like black liberals, saw gangsta rap as a major contributor to black antisocial behavior, and it therefore directed its efforts toward suppressing its influence through mentorship and moral guidance. This is not to say that such measures reflected a shift in the organization's methods for dealing with black social pathology. As noted before, the Nation has always assumed that it could mitigate black pathology by targeting blacks' supposed immorality. Yet black liberals' embrace of this idea by way of underclass ideology and neoliberalism meant that black politics had generally shifted toward the right on racial matters. Therefore, black censorship gives us a window onto the conservative nature of black politics in the 1990 s and 2000s.

\footnotetext{
${ }^{182}$ C. Delores Tucker, "Remarks at the Million Family March," Vital Issues: The Journal of African American Speeches 15, nos. 4 and 5 (Fall-Winter 2005): 89.

${ }^{183}$ Louis Farrakhan, "Message to the Hip-Hop Summit in New York," MP3 audio, June 13, 2001, 1:15:25-1:1:15:45.
} 


\section{Rappers}

Throughout its involvement in the rap censorship movement, the NOI had hoped that gangsta rappers would produce content that discouraged black pathology. While many of them continued to make music that celebrated crime, violence, sexual promiscuity, etc., a few answered its clarion call. This is not to suggest that the Nation was the first to demand that rappers produce such music. As mentioned before, this had been an integral part of the NPCBW's Entertainment Commission's mission since its inception. Yet the few who were inspired by the Nation's message would make music in this vein.

One of these rappers was Ice-T. Born Tracy Marrow, Ice-T was raised in South Los Angeles with relatives. A high school dropout and teen father, Ice-T turned to the illicit economy to survive, where he robbed, pimped girls and women, and sold drugs. While such subjects comprised the bulk of his musical output in the 1980s and early 90s, he started to produce more socially-conscious music by the mid-90s. In his 1996 song "I Must Stand," for instance, he recounts how seeing his friends getting incarcerated convinced him to abandon his criminal lifestyle. ${ }^{184}$ He explains how the Million Man March inspired him to write the song:

That was a song where you had to be in the right place at the right time. I thought at the time I had come a long way from the streets to here, and I thought to myself, How did that happen?' The main message in that march is that we have got to stand strong...It was a way of saying, What about you, black man? Are you taking care of your family? Are you respecting your woman?"185

As further evidence of his embrace of the NOI's message, he contributed lyrics to the song "Where Ya At?” which was a single released from the album One Million Strong, a compilation rap album that commemorated the Million Man March. Following a brief

\footnotetext{
${ }^{184}$ Ice-T, "I Must Stand,” MP3 Audio, track 5 on Ice-T VI: Return of the Real, Priority Records, 1996. 185“'Gangsta's paradise: Return of real Ice-T," Sunday Star Times (Auckland) (Nexis Uni), June 16, 1996, accessed June 6, 2020, https://advance-lexis-com.libproxy.lib.ilstu.edu/api/document?collection=news\&id=urn:content Item:3S4T-J570-0001-P424-00000-00\&context=1516831.
} 
commentary by rapper Ice Cube, Ice-T raps about black crime and the three-strike rule, suggesting that proper behavior could serve as a deterrent to prison: "brothers gonna have to put themselves in check/three strikes you're in the penzo/chained to your neck." ${ }^{186}$

Another rapper who took to the NOI's message was Ice Cube. Shortly after leaving N.W.A. to embark on a solo career, Cube gave several interviews where he discussed the Nation's influence on his thinking about black social issues. He released his second solo album Death Certificate in 1991. The album was divided into two halves: the "Death Side," which contained songs dealing with subjects typical of gangsta rap, such as crime and sexual promiscuity, and the "Life Side," which addressed more socially-conscious themes like the spread of sexually transmitted disease (STDs) in black communities and the ending of gang warfare. As explained on the album's first track, the Death Side was a "mirror image of where [African Americans] are today" while the Life Side was a "vision of where we need to go." In the album's liner notes, he praised the Nation and called for blacks to join the organization. ${ }^{187}$ In his song "Us," which is off the Life Side of the album, Cube faults African Americans for their willingness to engage in self-destructive behavior. For one, he suggests that the federal government is justified in cutting off welfare to black women because of rampant illegitimacy among them: "Four or five babies on your crotch/And you expect Uncle Sam to help us out?" He also explains why he felt that black men were unable to be good fathers: "I beat my wife and children to a pulp/ When I get drunk and smoke dope...And I'm havin' more babies than I really can afford/In jail 'cause I can't pay the mother."188

\footnotetext{
${ }^{186}$ Ice-T et al., "Where Ya At?” MP3 Audio, track 1 on One Million Strong, Solar Records, 1995.

${ }^{187}$ Ice Cube, Death Certificate, MP3 Audio, Priority Records, 1991.

${ }^{188}$ Ice Cube, "Us," track 19 on Death Certificate.
} 
Both Ice-T and Cube show how gangsta rappers could produce music that was in line with the Nation's censorship aims. Ice-T's lyrics, for instance, reveals that he saw black crime simply as an outgrowth of bad choices that were divorced from broader political and economic circumstances. Cube, on the other hand, not only draws on arguments about the supposed connection between welfare and illegitimacy, but also scolds black men for failing to live up to their responsibilities as fathers. Therefore, Ice-T's and Cube's music speak to neoliberal explanations for black inequality.

\section{Conclusion}

When Moynihan penned his infamous study in 1965, it was met with opposition from black liberals and civil rights advocates. They felt that it blamed blacks for their own plight and diverted attention away from structural explanations for racial inequality. Given the centrality of their views on racial inequality in black politics at the time, it is reasonable that Moynihan's view on the subject would remain a marginal one in black politics for roughly the next two decades.

This changed during the 1990s, when neoliberalism began to cast its shadow over black politics. Black liberals began to believe that antisocial behavior was a major cause of black inequality. Because this belief had been a central idea in the Nation's ideology since its inception, the organization started to gain legitimacy and take center stage in the black political arena during this period. Therefore, neoliberalism helped to establish a consensus between these two factions on the causes of black inequality in the post-civil rights era.

This new consensus could be seen in the Million Man March and its impact on the gangsta rap censorship movement. Organizers of the March expressed the view that irresponsible 
black men were to blame for many of the social issues that blacks faced, and that black men could better themselves, and in turn better the conditions of blacks in general, if they practiced atonement, reconciliation, and responsibility. In this sense, the goals of the March were inextricably linked to those of the censorship movement, since the latter tended to blame major social issues on black male rappers and expressed the belief that they could ameliorate these issues by producing music that served to counter antisocial themes. Therefore, the March's mission fit neatly within the purview of rap censorship.

Much in the same vein as black liberals, the Nation and the event it inspired (i.e. the Million Woman March), attempted to disrupt the supposed causal relationship between gangsta rap and crime, violence, sexual deviancy, and family disorganization. The Nation used mass gatherings and summits to call attention to the negative effects that the genre had on its black listeners. What separated the NOI from black liberals, however, was its more pronounced belief that the genre could be used as a redemptive force to cure blacks of social pathology.

The type of music that resulted from the Nation's influence was music that called for blacks to change their behavior as a way of bettering their conditions. In Ice-T's and Cube's views, black crime and unstable black families, respectively, were products of abhorrent behavior. Conformity, therefore, was a key remedy to such issues, which was reflective of neoliberalism. 


\section{CONCLUSION}

After 2000, organized censorship efforts against gangsta rap began to decline. This does not mean, however, that criticisms of the genre were any less prevalent. For many commentators, in fact, rap remained a primary reason as to why blacks experienced social pathology at a higher rate than other groups. By looking at a few examples, we can see how central rap remained in discussions about social pathology.

One of the most vocal critics to come out of the post-censorship era was John McWhorter. A Columbia University linguist professor and self-described "cranky liberal Democrat," ${ }^{189}$ McWhorter is a regular commentator on issues related to black culture and society. In 2004, he penned an essay in the Manhattan Institute's City Journal that echoed arguments made by censors in the 1990s.

In his essay, he argued that while the Civil Rights Movement created gains for African Americans, those gains were being undone by black antisocial behavior associated with gangsta rap. Asserting that the "rise of nihilistic rap has mirrored the breakdown of community norms among inner-city youth over the last couple of decades," McWhorter complained that the genre convinces them that "there's nothing more authentic than ghetto pathology." He goes on to blame rap for encouraging conditions like violence and unemployment in black urban areas. ${ }^{190}$

Another prominent voice in the post-censorship era was entertainer Bill Cosby. By the early 2000s, Cosby had become an outspoken critic of black youth behavior. His views on the subject were made clear in his infamous 2004 Pound Cake speech. The speech, which was given

\footnotetext{
189“'Douglas Todd: Race, identity and religion: Five thinkers offer fresh takes," Postmedia Breaking News (Nexis Uni), January 9, 2020, accessed June 10, 2020, https://advance-lexis-com.libproxy.lib.ilstu.edu/api/document? collection=news\&id=urn:contentItem:5XY2-8HN1-F125-130B-00000-00\&context=1516831.

${ }^{190}$ John McWhorter, "How Hip-Hop Holds Blacks Back," City Journal (Nexis Uni) 13, no. 3 (July 2003): 66-75, accessed June 10, 2020, https://advance-lexis-com.libproxy.lib.ilstu.edu/api/document?collection=news\&id=urn: contentItem:4950-5S40-001B-G14X-00000-00\&context=1516831.
} 
at a NAACP awards ceremony that commemorated the $50^{\text {th }}$ anniversary of the Brown vs. Board of Education Supreme Court decision, attributed many of the challenges confronting African Americans in the post-civil rights era to dysfunctional behavior.

Centering his speech on weak family structures, Cosby argued that there was an increase in incarceration, high school drop-out rates, and out-of-wedlock births among young African Americans because black parents failed to offer their children proper moral guidance. He also criticized the way blacks spoke and dressed, suggesting that the former kept them out of professional occupations. As a nod to the NOI's efforts to suppress black social pathology, he also credited the organization with crime reduction in black inner cities. ${ }^{191}$

While Cosby does not make any explicit references to gangsta rap in his speech, his written work reveals that he saw the genre as a major contributor to black social pathology. In 2007, Cosby authored a book with noted black psychologist and longtime collaborator Dr. Alvin F. Poussaint that explored this very subject. ${ }^{192}$ In it, both Cosby and Poussaint assert that black children's preference for broken English, which they adopt from rappers, is largely responsible for their high drop-out rates. ${ }^{193}$ They also argue that gangsta rap promotes the "moral breakdown of the family" by encouraging early pregnancy and irresponsible fathers. ${ }^{194}$ Finally, they recommended that black activists, institutions, organizations, and Congress do more to censor $\operatorname{rap}^{195}$

\footnotetext{
${ }^{191}$ Bill Cosby, "Dr. Bill Cosby Speaks at the 50th Anniversary Commemoration of the "Brown v. Topeka Board of Education' Supreme Court Decision, May 22, 2004,” Black Scholar 34, no. 4 (Winter 2004): 2-5.

${ }^{192}$ Poussaint had collaborated with Cosby on the latter's hit sitcom The Cosby Show in the 1980s and 90s, where he served as a consultant. See Michael E. Hill, "BILL COSBY/ His New Series if 'Based on My Personal Experience," Washington Post (Nexis Uni), September 16, 1984, 9, accessed June 10, 2020, https://advance-lexiscom.libproxy.lib.ilstu.edu/api/document?collection=news\&id=urn:contentItem:3S8G-KDW0- 0009-X1WH-0000000\&context $=1516831$.

${ }^{193}$ Bill Cosby and Alvin F. Poussaint, Come on People: On the Path from Victims to Victors (Nashville: Thomas Nelson, 2007), 119.

${ }^{194}$ Cosby and Poussaint, Come on People, 143.

${ }^{195}$ Cosby and Poussaint, Come on People, 145, 154.
} 
Like McWhorter, Cosby, and Poussaint, Barack Obama has also attempted to find connections between black social pathology and rap music. In various speeches he has given over the years, Obama has attributed several conditions in black inner cities, such as poor education and other forms of "ghetto social malaise" to parental neglect. ${ }^{196}$ To address the high rates of unemployment, incarceration, and drop-outs rates among inner-city black males, Obama founded the My Brother's Keeper (MBK) Initiative in 2014, which is aimed at helping "young men of color facing especially tough odds to stay on track and reach their full potential," as stated in a speech outlining the goals of the program. The program seeks to help young black males overcome these conditions through mentorship and community leadership. ${ }^{197}$

Last year, Obama hosted and spoke at the first major MBK event in Oakland, California. Rather than addressing issues that keep poor black males from exceling in society, like substandard schools and a lack of employment opportunities, Obama centered his discussion on the need for young black men to correct their personal defects. He argued that they should reject notions from hip hop that aggressive behavior is somehow a marker of black male authenticity. ${ }^{198}$

While black liberals after 2000 continued to identify rap music as a major cause of black social pathology, the NOI continued to act as a mediator in conflicts between rap artists. Concerns over how the Tupac and Biggie conflict led to escalating tensions in the hip-hop world led Farrakhan to get involved in one of the most highly publicized rap beef in the early 2000s:

\footnotetext{
${ }^{196}$ Toure F. Reed, "Between Obama and Coates," Catalyst 1, no. 4 (Winter 2018): 38.

197،"REMARKS BY THE PRESIDENT ON 'MY BROTHER'S KEEPER" INITIATIVE,”’ States News Service (Nexis Uni), February 27, 2014, accessed June 10, 2020, https://advance-lexis-com.libproxy. lib.ilstu.edu/api/ document?collection=news\&id=urn:contentItem:5BMG-F001-JCBF-S0B2-00000-00\&context=1516831.

${ }^{198}$ James Hohmann, “The Daily 202: Barack Obama criticizes pop culture for promoting the wrong values to young men," Washington Post Blogs (Nexis Uni), February 20, 2019, accessed June 10, 2020, https://advance-lexis-com. libproxy.lib.ilstu.edu/api/document?collection=news\&id=urn:contentItem:5VG5-P1D1-JB4M-V185-00000-00\& context $=1516831$.
} 
the $50 \mathrm{Cent} / \mathrm{Ja}$ Rule feud. While 50 claimed that the feud started after Rule saw him with a man who robbed him, Rule claimed that it started after 50 felt snubbed by he and his associates during a video shoot. Regardless of the feud's origins, both rappers exchanged diss tracks toward one another from 1999-2003. Their beef started to die down after 2003, though both rappers still exchange insults via interviews and social media. ${ }^{199}$

Farrakhan sat down with Ja Rule in a 2003 interview to settle the dispute between the two rappers. He warned Rule to exercise caution when addressing his disputes with rappers publicly, since, like the Tupac and Biggie conflict, such disputes tended to contribute to violence amongst their fans in black communities. He hoped instead that both 50 Cent and Rule would use their music to uplift black youth. ${ }^{200}$

Farrakhan's belief in rap's positive impact on black youth was embodied in a central theme of the Millions More Movement: artistic/cultural development. Held on the ten-year anniversary of the Million Man March, the purpose of the Movement was to address issues that Farrakhan felt were not adequately addressed during the former, including black economic development and the government's role in helping poor blacks. He also believed that the Movement could encourage black artists to "do better by themselves and by [their] people" by promoting positive messages. $^{201}$

Such a call seems to have affected NOI-affiliated rapper DA Smart's musical output. In

\footnotetext{
${ }^{199}$ Roisin O'Connor, "50 Cent and Ja Rule: A beef history; After 50 Cent trolled Ja Rule by purchasing 200 tickets to his concert - so the seats would be empty - here's a reminder of one of the longest-running feuds in hip hop," The Independent (United Kingdom)(Nexis Uni), November 7, 2018, accessed June 18, 2020, https://advance-lexis-com. libproxy.lib.ilstu.edu/api/document?collection=news\&id=urn:contentItem:5TNR-NXT1-JCJY-G0FP-00000-00\& context=1516831.

${ }^{200}$ Salim Muwakkil, "Farrakhan and the Beefs of Rap," In These Times (Nexis Uni), January 5, 2004, accessed June 15, 2020, https://advance-lexis-com.libproxy.lib.ilstu.edu/api/document?collection=news\&id=urn:contentItem:4B9 5-J540-001B-S3RM-00000-00\& context=1516831.

${ }^{201}$ Clarence Waldron, "Minister Louis Farrakhan Says Upcoming Millions More Movement March Is 'A CALL TO ACTION,", Jet (Nexis Uni), October 10, 2005, accessed June 10, 2020, https://advance-lexis-com.libproxy.lib.ilstu. edu/api/document?collection=news\&id=urn:contentItem:4H8D-BT80-006G-201N-00000-00\&context=1516831.
} 
2005, he released an album titled after the Movement. In one of the album's songs, which was originally released during the Million Man March, Smart rejects the welfare state and calls for blacks to adopt a program of self-help to better their economic conditions. He also asserts that while black women had traditionally led the black family, they needed to "stay home" during the March and allow black men to prove their worth as husbands and fathers. ${ }^{202}$

Another song off the album, "The Woman," builds on the familial themes outlined in Smart's March song. He promotes a conservative role for black women in their families: he celebrates them as mothers and as the initial nurturers of black males. He also urges them to see themselves for more than their sexual prowess and act as support systems for black men. ${ }^{203}$

Black liberals' and the NOI's continued investment in behavioral solutions to black social issues via rap censorship did little to lessen the growing rates of school dropouts, joblessness, crime, and family dissolution among poor African Americans. Statistics in the post-censorship era, therefore, can show us why such issues can largely be understood in the context of blacks' economic circumstances.

Scholars have looked at the link between poverty and education. Russell W. Rumberger finds that African-American children who have a low socioeconomic status tend to have a higher dropout rate than their more affluent counterparts. He posits that this is the case because the former often lack access to resources that are essential to academic success, such as support from well-educated parents who have high incomes. ${ }^{204}$ Two other scholars suggest that many poor black high schoolers drop out because they see paid work as a better alternative to school. ${ }^{205}$ One

\footnotetext{
${ }^{202}$ D.A. Smart, “One in a Million (Official Million Man March Song)," MP3 audio, track 8 on Million More Movement, Terror Records, 2005, originally released in 1995.

${ }^{203}$ D.A. Smart, "The Woman," MP3 audio, track 7 on Million More Movement, Terror Records, 2005.

${ }^{204}$ Russell W. Rumberger, Dropping Out: Why Students Drop Out of High School and What Can Be Done About It (Cambridge: Harvard University Press, 2011), 191.

${ }^{205}$ Christen L. Bradley and Linda A. Renzulli, “ The Complexity of Non-Completion: Being Pushed or Pulled to Drop Out of High School," Social Forces 90, no. 2 (December 2011): 525.
} 
source estimated that "[b]y the turn of the 21 st century in central cities," which tend to have high concentrations of poverty, the "Black male school dropout rates were 50\% or more."206

Like dropout rates, unemployment among African Americans could also be attributed to broader economic issues. One article, for instance, assessed the impact that the American Recovery and Reinvestment Act of 2009 had on unemployment rates among African Americans and Latinos living in Los Angeles and Atlanta between 2009 and $2011 .^{207}$ It revealed that while the stimulus package was aimed at alleviating macroeconomic issues like national unemployment, it did little for unemployment among blacks in these cities, which increased from $18.2 \%$ and $15.7 \%$ in 2009 to $25.2 \%$ and $20.7 \%$, respectively. ${ }^{208}$ The authors suggest that the rate increased because the package failed to address the microeconomic issues associated with minorities in these areas, such as being geographically isolated from good-paying jobs. ${ }^{209}$

In 2018, Earl Fredrick published an article in the Harvard Public Health Review that looked at how poverty contributed to homicide rates in predominately black Chicago neighborhoods between 2005 and 2009. He found that there were higher instances of homicide in neighborhoods with concentrated poverty. Englewood and West Englewood, which were 46.6\% and $34.4 \%$ below the poverty line, respectively, annually had on average 22 and 18 homicides, respectively. Conversely, he notes that affluent white Chicago neighborhoods, like Lakeview and O’ Hare, reported only one murder annually during the same years. ${ }^{210}$

\footnotetext{
${ }^{206}$ Joseph Richardson and Christopher St. Vil, "Putting in Work: Black Male Youth Joblessness, Violence, Crime, and the Code of the Street," Spectrum: A Journal on Black Men 3, no. 2 (Spring 2015): 74.

${ }^{207}$ This act was geared toward stimulating job growth during the Great Recession, where millions of Americans had lost their jobs. See Vance Grey et.al, "American Recovery and Reinvestment Act of 2009: A Political Analysis of Its Impact on Black and Latino Unemployment in the United States," Race, Gender, and Class 22, no. 3-4 (2015): $111,112$.

${ }^{208}$ Grey et. al, "American Recovery,” 127, 128, 130.

${ }^{209}$ Grey et. al, "American Recovery," 115, 117-118.

${ }^{210}$ Earl Fredrick, "Death, Violence, Health, and Poverty in Chicago," Harvard Public Health Review 19 (Fall 2018): $6,8,11$.
} 
These statistics should not suggest that poor blacks are somehow predisposed to violent, criminal behavior. There are often external factors that can be used to explain such behavior. Sociologist Elijah Anderson, for instance, examines how joblessness contributes to crime and violence. He argues that black youth that come from poor, deindustrialized urban areas where joblessness is common are often forced to partake in the illicit economy for economic gain. In this context, committing crimes and acts of violence, which would normally be considered deviations from mainstream norms, are viewed as legitimate forms of work. ${ }^{211}$

Black family instability can also be tied to economic deprivation. One 2019 report evaluated the state of education and employment for black families that resided in poor, lowincome areas in Atlanta. The report found that parents are often not able to send their children to good childcare programs in the city because of the high cost. In 2016, for instance, the average annual cost for these programs in Georgia was $\$ 7,644$, which made up nearly $30 \%$ of these families' annual median household income. The report also asserted that this not only retards children's academic success, but also contributes to parents' unemployment, since they might have no one to look after their young children while they are at work or look for work. ${ }^{212}$ This increases the likelihood that parents will participate in the illicit economy, and therefore become incarcerated and leave their children neglected. This shows that such conditions cannot be solely attributed to pathology.

Censors' preference for behavioral approaches to black social issues despite evidence that such issues are linked to economic conditions shows how black rap censorship was the triumph

\footnotetext{
${ }^{211}$ Elijah Anderson, Code of the Street: Decency, Violence, and the Moral Life of the Inner City (New York: W. W. Norton \& Company, 1999), 110-111, 135.

${ }^{212}$ The Annie E. Casey Foundation, Changing the Odds: Progress and Promise in Atlanta (Baltimore: The Annie E. Casey Foundation, 2019), 13, accessed June 15, 2020, https://www.aecf.org/m/resourcedoc/aecf-changingtheodds2019.pdf\#page $=6 \ldots$
} 
of neoliberalism in black politics. Black liberals pursued censorship to address the myriad of social issues that blacks faced in the post-WWII era. The measures they utilized toward this end were based on a belief that such issues were the product of behavioral issues rather than a dearth of economic opportunities, which is why they sought to reduce crime through mentorship rather than job creation, or identified immorality as a central cause of black family breakdown. The NOI's censorship efforts were also reflective of a neoliberal turn in black politics. The Nation never adopted neoliberalism per se, since the organization has always been conservative in racial matters. Yet both black liberals' and the NOI's acceptance of behavioral solutions to black social issues meant that they reached a consensus on the causes of black inequality in contemporary society. This consensus must be seen in the same context as the anti-crime and welfare reform measures of the 1990s, since they all reflected similar assumptions about black crime, female sexual deviancy, and family life. By looking at black censorship in this context, it can be seen that it was a facet of a broader rightward shift in black and American politics, and not so much a cultural or generational issue as some scholars suggest.

In making this argument, this project does not seek to condemn censors for their choice of politics. Rather, I argue that their politics were understandable given the historical context. The political narrative among censors and their contemporaries was that civil rights and affirmative action policies had led to significant gains for blacks, and their failure to take advantage of the opportunities brought about by these policies were reflective of their own shortcomings. Therefore, their approach to dealing with black social issues did not so much reflect a retreat from their commitment to black equality but more so the means they believed it took to achieve it-changing individual behavior rather than broader structural forces. Therefore, censors are a product of their historical moment. 
While it is not my goal to vilify black rap censorship and neoliberal politics, this project should nevertheless caution social scientists, politicians, policymakers, and the general population about using behavioral measures as a panacea for major black social issues. This is not to suggest that behavior does not sometime play a role in personal outcomes: some people commit crimes and form broken families due to moral depravity. But this is true of everyone, and it fails to explain why poor blacks suffer from these conditions at a disproportionally higher rate than other groups. Because such behavioralist explanations do not suffice, we must instead look to their peculiar historical experience: deindustrialization, automation, globalization, and the federal government's refusal to address the effects that these economic changes had on black urban life. Such an analysis sheds light on how large-scale social issues cannot simply be byproducts of personal immorality; broader political-economic factors can often constrain the type of opportunities that a group has, which can lead to these conditions.

Finally, this project should show that neoliberal politics have not been up to the task of improving the conditions of poor, urban blacks. Any politics that fail to acknowledge the toll that political-economic forces have had on their communities must be discarded. In rejecting such politics, we can conclude that we must instead advance politics that effectively address the conditions that give rise to the issues that they face. 


\section{BIBLIOGRAPHY \\ Primary Sources:}

Databases:

Nexis Uni

EBSCOhost

Books:

Auletta, Kevin. The Underclass. New York: Random House, 1982.

Cosby, Bill, and Alvin F. Poussaint. Come on People: On the Path from Victims to Victors. Nashville: Thomas Nelson, 2007.

Giddings, Paula. When and Where I Enter: The Impact of Black Women on Race and Sex in America. New York: William Morrow and Company, Inc., 1984.

Madhubuti, Haki R. and Maulana Karenga, eds. Million Man March/Day of Absence: A Commemorative Anthology: Speeches, Commentary, Photography, Poetry, Illustrations, Documents. Chicago: Third World Press, 1996.

Obama, Barack. The Audacity of Hope: Thoughts on Reclaiming the American Dream. New York: Random House, 2006.

Wilson, William J. The Truly Disadvantaged: The Inner City, the Underclass, and Public Policy. 2nd ed. Chicago: University of Chicago Press, 2012.

Articles:

Bock, James. “Thinking Young, NAACP Embraces Rap.” Baltimore Sun, February 10, 1994. Accessed May 20, 2020. https://www. baltimoresun.com/news/bs-xpm-1994-02-101994041108-story.html.

“C. Delores Tucker, 1927-2005.” The Journal of Blacks in Higher Education, no. 49 (Autumn, 2005): 59. 
Drexler, Deborah L. "Basic Requirements of the Family and Medical Leave Act." The Compleat Lawyer 10, no.4 (Fall 1993): 6-8.

Joint Center for Political and Economic Studies. "Political Trend Letter." FOCUS 22, no 2 (1994): 1-4.

Moynihan, Daniel Patrick. "Employment, Income, and the Ordeal of the Negro Family." Daedalus 94, no. 4 (1965): 745-770.

Noel, Peter. "Escape from the Nation of Islam." The Village Voice, September 1, 1998. Accessed June 18, 2020. https://www.villagevoice.com/1998/09/01/escape-from-thenation-of-islam/.

--.“Hip Hop War.” The Village Voice, April 24, 2001. Accessed June 18, 2020. https://www. villiagevoice.com/2001/04/24/hip-hop-war/.

Philips, Chuck. 'Rap Defense Doesn't Stop Death Penalty: 'The music affected me,' says Ronald Ray Howard. 'That's how it was that night I shot the trooper.'" Los Angeles Times, July 15, 1993. Accessed May 20, 2020. http://articles.latimes.com/1993-0715/entertainment/ca-13309_1_ronald-ray-howard.

Ross, Sonya. “A Lonely Crusader Against Gangsta Rap.” Chicago Tribune (ProQuest), September 15, 1995. Accessed May 20, 2020. https://search-proquest-com.libproxy.lib. ilstu.edu/chicagotribune/docview/2074649969/fulltextPDF/DFA3955009F54CDAPQ/1?a ccountid=11578.

Tucker, C. Delores. "Publisher's Statement." Vital Issues: The Journal of African American Speeches 6, no. 2 (1996): ii. 
Speeches:

Coney, Asia. "Remarks at the Million Woman March." Vital Issues: The Journal of African American Speeches 7, no.4 (1997): 4-5.

Cosby, Bill. "Dr. Bill Cosby Speaks at the 50th Anniversary Commemoration of the 'Brown v. Topeka Board of Education' Supreme Court Decision, May 22, 2004.” Black Scholar 34, no. 4 (Winter 2004): 2-5.

Farrakhan, Louis. “Chicago Hip Hop Summit.” MP3 Audio, April 3, 1997, 2:38:03.

--. “Chicago Hip Hop Summit (2).” MP3 Audio, May 13, 1997, 2:19:28.

--. “Message to the Hip-Hop Summit in New York.” MP3 Audio, June 13, 2001, 2:20:48.

--. "Million Family March.” C-SPAN, July 14, 2000, 41:50. Accessed June 18, 2020. https://www.c-span.org/video/?158235-1/million-family-march.

--. “The Honorable Minister Louis Farrakhan Hip Hop Summit 1997 pt.1.” Chicago, Il. Filmed on April 3, 1997. YouTube video, 9:51. https://www.youtube.com/watch?v=fQJRPKyKp Gw.

Raegan, Ronald. "Radio Address to the Nation on Welfare Reform." The American Presidency Project, February 15, 1986. Accessed June 18, 2020, https://www.presidency.ucsb.edu/ documents/radio-address-the-nation-welfare-reform- 0 .

Sister Souljah. "Remarks at the Million Woman March." Vital Issues: The Journal of African American Speeches 7, no.4 (1997): 7-8.

Tucker, C. Delores. "Remarks at the George H. Gallup International Institute Conference." Vital Issues: The Journal of African American Speeches 9, no. 4 (Winter 1999): 12-17.

--. "Remarks at the Million Family March.” Vital Issues: The Journal of African American Speeches 15, nos. 4 and 5 (Fall-Winter 2005): 89-91. 
--. "Remarks at the National Political Congress of Black Women's 16th Annual Awards Brunch.” Vital Issues: The Journal of African American Speeches 10, no. 4 (Winter 2000): 20-22.

--."Statement of C. Delores Tucker." In Shaping Our Responses to Violent and Demeaning Imagery in Popular Music: Hearing Before the Subcommittee on Juvenile Justice of the Committee on the Judiciary, United States Senate, One Hundred Third Congress, Second Session ... February 23, 1994, 11-14.

--. "Violence Against Women.” C-SPAN, January 6, 1994, 23:37-35:14. Accessed May 20, 2020. https://www.c-span.org/video/?53577-1/violence-women.

Musical Recordings:

Bytches With Problems. The Bytches. MP3 Audio. Def Jam Columbia, 1991.

D.A. Smart. Million More Movement. MP3 Audio. Terror Records, 2005.

Ice Cube. Death Certificate. MP3 Audio. Priority Records, 1991.

Ice-T. "I Must Stand.” MP3 Audio. Track 5 on Ice-T VI: Return of the Real, Priority Records, 1996.

Ice-T et al. "Where Ya At?” MP3 Audio. Track 1 on One Million Strong, Solar Records, 1995. Secondary Sources:

Books:

Alexander, Michelle. The New Jim Crow: Mass Incarceration in the Age of Colorblindness. New York: New Press, 2011.

Anderson, Elijah. Code of the Street: Decency, Violence, and the Moral Life of the Inner City. New York: W. W. Norton \& Company, 1999.

Carter, Daryl A. Brother Bill: President Clinton and the Politics of Race and Class. Fayetteville: University of Arkansas Press, 2016. 
Conner, Alice O'. Poverty Knowledge: Social Science, Social Policy, and the Poor in TwentiethCentury U.S. History. Princeton: Princeton UP, 2001.

Hancock, Ange-Marie. The Politics of Disgust: The Public Identity of the Welfare Queen. New York: New York University Press, 2004.

Hartman, Andrew. A War for the Soul of America: A History of the Culture Wars. Chicago: Chicago UP, 2015.

Hinton, Elizabeth. From the War on Poverty to the War on Crime: The Making of Mass Incarceration in America. Cambridge: Harvard UP, 2016.

Hunter, James Davidson. Culture Wars: The Struggle to Define America. New York: Basic Books, 1991.

Kelley, Robin D.G. Yo Mama's Disfunktional!: Fighting the Culture Wars in Urban America. Boston: Beacon Press, 1997.

Kitwana, Bakari. The Hip-Hop Generation: Young Blacks and the Crisis in African-American Culture. New York: Basic Books, 2003.

McCann, Bryan J. Mark of Criminality: Rhetoric, Race, and Gangsta Rap in the War-On-Crime Era. Tuscaloosa: University of Alabama Press, 2017.

Reed, Adolph, Jr., ed. Without Justice For All: The New Liberalism and Our Retreat From Racial Equality. Colorado: Westview Press, 1999.

Reed, Toure F. Toward Freedom: The Case Against Race Reductionism. New York: Verso Books, 2020.

Rumberger, Russell W. Dropping Out: Why Students Drop Out of High School and What Can Be Done About It. Cambridge: Harvard University Press, 2011. 
Smith, Ann Marie. Welfare Reform and Sexual Regulation. Cambridge: Cambridge University Press, 2007.

Taylor, Keeanga-Yamahtta. Race for Profit: How Banks and the Real Estate Industry

Undermined Black Homeownership. Chapel Hill: University of North Carolina Press, 2019.

White, Deborah Grey. Too Heavy a Load: Black Women in Defense of Themselves, 1894-1994. New York: W.W. Norton \& Company, 1999.

Articles:

Alexander-Floyd, Nikol G. “'We Shall Have Our Manhood:' Black Macho, Black Nationalism, and the Million Man March.” Meridians 3, no. 2 (2003): 171-203.

Bradley, Christen L. and Linda A. Renzulli. “ The Complexity of Non-Completion: Being Pushed or Pulled to Drop Out of High School.” Social Forces 90, no. 2 (December 2011): 521-545.

Brock, Nailah R. "African Americans and Welfare Time Limits: Comparative Analysis of State Time Limit Policies under the Personal Responsibility and Work Opportunity and Reconciliation Act of 1996.” Journal of Black Studies 39, no. 6 (2009): 962-973.

Chastagner, Claude. "The Parents' Music Resource Center: From Information to Censorship.” Popular Music 18, no.2 (1999): 179-192.

Clegg, John. and Adaner Usmni. “The Economic Origins of Mass Incarceration.” Catalyst 3, no. 3 (Fall 2019): 9-53.

Fredrick, Earl. "Death, Violence, Health, and Poverty in Chicago.” Harvard Public Health Review 19 (Fall 2018): 1-25.

Geronimus, Arline T. “Teenage Childbearing and Personal Responsibility: An Alternative View.” Political Science Quarterly 112, no. 3 (Autumn 1997): 405-430. 
Grey, Vance et.al. “American Recovery and Reinvestment Act of 2009: A Political Analysis of Its Impact on Black and Latino Unemployment in the United States.” Race, Gender, and Class 22, no. 3-4 (2015): 107-135.

Hausmann, Julilly Kohler-"Welfare Crises, Penal Solutions, and the Origins of the "Welfare Queen.” Journal of Urban History 41, no.5 (2015): 756-771.

Lang, Clarence and Sundiata Keita Cha-Jua. "Providence, Patriarchy, Pathology: Louis Farrakhan's Rise \& Decline.” New Politics 6, no. 2 (Winter 1997): 47-71. https:// archive.newpol.org/issue22/chajua22.htm

Lipsitz, George. “The Hip Hop Hearings: Censorship, Social Memory, and Intergenerational Tensions Among African Americans." In Generations of Youth: Youth Culture and History in Twentieth-Century America. Edited by Joe Austin and Michael Nevin Willard, 395-411. New York: New York UP, 1998.

Massey, Douglas S. "The Legacy of the 1968 Fair Housing Act.” Sociological Forum 30, no. S1 (June 2015): 571-588.

Ogbar, Jeffrey O. G. "Slouching Toward Bork: The Culture Wars and Self-Criticism in Hip-Hop Music.” Journal of Black Studies 30 (1999): 164-183.

Reed, Toure F. "Between Obama and Coates." Catalyst 1, no. 4 (Winter 2018): 9-54.

--."Why Moynihan Was Not So Misunderstood at the Time: The Mythological Prescience of the Moynihan Report and the Problem of Institutional Structuralism." nonsite.org, September 4, 2015. Accessed June 18, 2020. http://nonsite.org/article/why-moynihan-was-not-somisunderstood-at-the-time. 
Richardson, Joseph and Christopher St. Vil. "Putting in Work: Black Male Youth Joblessness, Violence, Crime, and the Code of the Street." Spectrum: A Journal on Black Men 3, no. 2 (Spring 2015): 71-98.

\section{Dissertations/Theses:}

Conway, Jordan A. “Living in a Gangsta’s Paradise: Dr. C. Delores Tucker's Crusade Against Gangsta Rap Music in the 1990s.” MA thesis, Virginia Commonwealth University, Virginia, 2015.

\section{Reports:}

The Annie E. Casey Foundation. Changing the Odds: Progress and Promise in Atlanta. Baltimore: The Annie E. Casey Foundation, 2019. Accessed June 15, 2020. https:// www.aecf.org/m/resourcedoc/aecf-changingtheodds-2019.pdf\#page $=6 \ldots$ 